Portland State University

PDXScholar

$1-1-2011$

\title{
A comparative case study of newspaper coverage of the Umatilla Chemical Weapons Depot/Incinerator from 1994 to 1998.
}

Rogue Elliott Robertson

Portland State University

Follow this and additional works at: https://pdxscholar.library.pdx.edu/open_access_etds Let us know how access to this document benefits you.

Recommended Citation

Robertson, Rogue Elliott, "A comparative case study of newspaper coverage of the Umatilla Chemical Weapons Depot/Incinerator from 1994 to 1998." (2011). Dissertations and Theses. Paper 315.

https://doi.org/10.15760/etd.315

This Thesis is brought to you for free and open access. It has been accepted for inclusion in Dissertations and Theses by an authorized administrator of PDXScholar. Please contact us if we can make this document more accessible: pdxscholar@pdx.edu. 
A Comparative Case Study of Newspaper Coverage of the Umatilla Chemical Weapons Depot/Incinerator from 1994 to 1998

by

Rogue Elliott Robertson

Thesis submitted for partial fulfillment of the requirements for the degree of

Master of Science

in

Communication

Thesis Committee:

Cynthia-Lou Coleman, Chair

Priya Kapoor

Susan Poulsen

Portland State University

2011 


\begin{abstract}
The purpose of this case study was to compare the news coverage of The Umatilla chemical weapons by examining newspapers from different communities: The Oregonian and The Hermiston Herald. The author examines solution frames, pluralistic frames, episodic frames, and thematic frames and compares them across two newspapers. The study found the difference was not significant when comparing the use of solution frames between The Hermiston Herald and The Oregonian. In addition, there was not a significant difference in use of pluralistic framing by The Hermiston Herald and The Oregonian. However, there was a significant difference in the sources presented in the newspaper articles. There was also a significant presence of episodic frames compared to thematic frames in both the newspapers under examination.
\end{abstract}




\section{DEDICATION}

I would like to dedicate this work to my Grandfather, Elliott Robertson, who passed away during this study. He was known to wear a fine hat and believed an excellent vocabulary to be key in realizing one's potential. 


\section{ACKNOWLEDGMENTS}

There are many people to thank for support and assistance in developing this study, and I apologize in advance to anyone not mentioned below. First, I would like to thank my parents, Bruce and Robin Robertson, for always espousing the value of education, providing motivation, and supporting my education in all variety of manners. I would also like to thank my partner, Abby Rae Scott, for motivating me to get back on campus, supporting my studies, editing my drafts, and having faith in my abilities. I would also like to thank Terri Briggs, of The Hermiston Herald, for her work which supplied valuable data. I must thank my two anonymous coders, whom without I would not have results. Next, I would like to thank my committee members, Dr. Cynthia-Lou Coleman, Dr. Susan Poulsen, and Dr. Priya Kapoor, for their understanding, patience, and guidance in this process. Finally, I wish to further acknowledge the invaluable contributions of my thesis advisor, Dr. Cynthia-Lou Coleman, for her endless editing of my numerous drafts, support of my petitions, and stellar counsel in my endeavor. Thank you all! 


\section{TABLE OF CONTENTS}

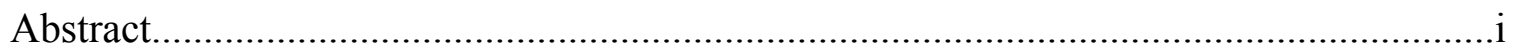

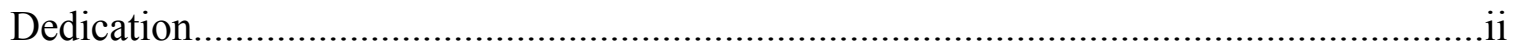

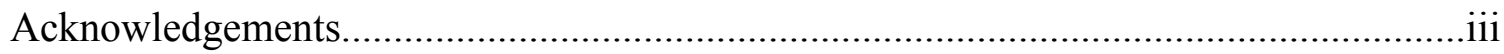

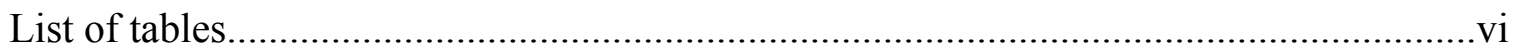

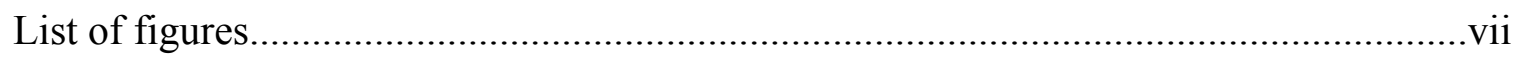

Chapter 1

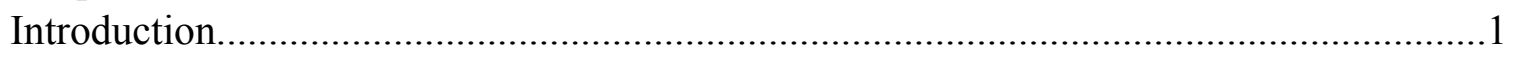

Chapter 2

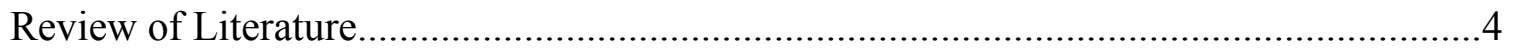

Chapter 3

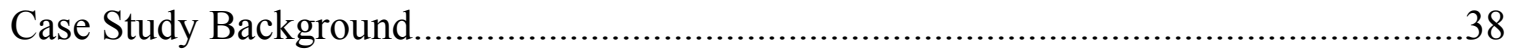

Chapter 4

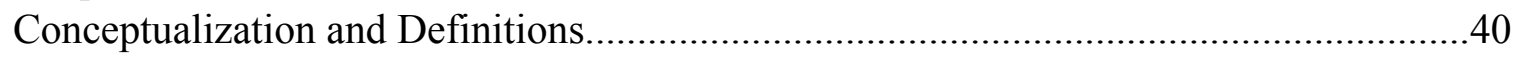

Chapter 5

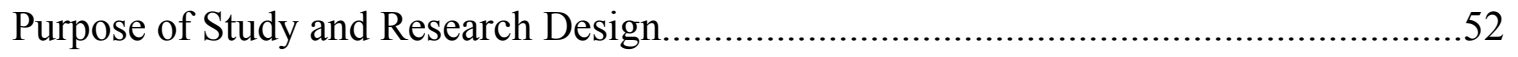

Chapter 6

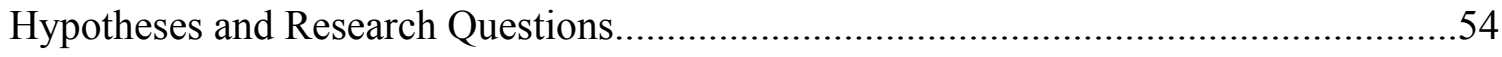

Chapter 7

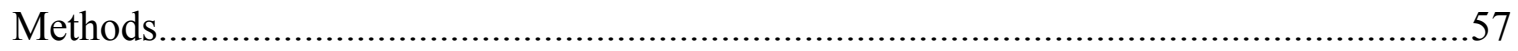




\section{Chapter 8}

Results.

Chapter 9

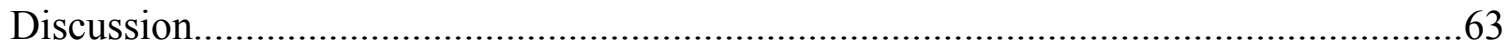

Chapter 10

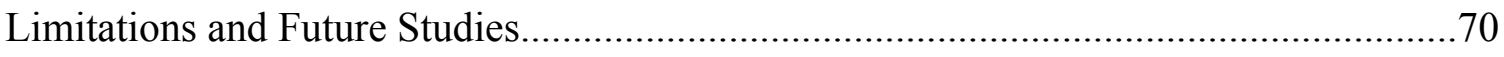

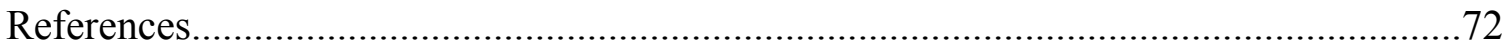

\section{APPENDICES}

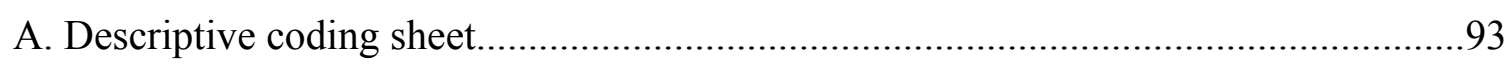

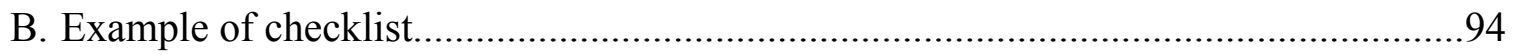




\section{LIST OF TABLES}

TABLE 1 Demographic characteristics of two cities........................................46

TABLE 2 Demographic characteristics of two cities (cont.).................................47

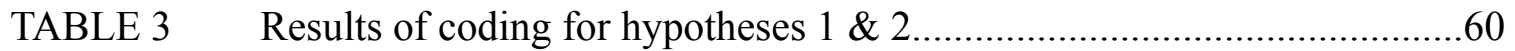

TABLE $4 \quad$ Results of coding for research questions...........................................62 


\section{LIST OF FIGURES}

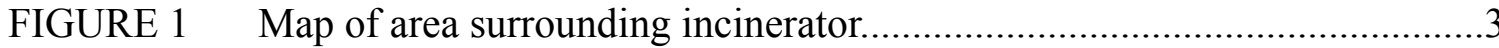

FIGURE 2 Episodic and thematic frame illustration.....................................................35

FIGURE 3 Information flow chart, from reporter to audience.....................................37

FIGURE 4 Race distribution of two communities...................................................48

FIGURE 5 Educational attainment of two communities...........................................49

FIGURE 6 Per capita Income of two communities.....................................................49

FIGURE 7 Sources identified in pluralistic frame....................................................61 


\section{Chapter 1. Introduction}

Why is there a 'free press', what function does it serve, is the function being performed, and how well? These are underlying questions I sought to answer in this study. However, the scope of research is narrower than these broad question imply. In this study I explore the use of "solution frames," and what I have termed "pluralistic frames," in news coverage of the chemical weapons stockpile in Eastern Oregon (Coleman \& Corbitt, 2003). I compared frame use across the two community newspapers in Portland, and Hermiston, Oregon. I examined frames from the construction or creation aspect within the news reporter's domain. Although cognitive processing of frames will not be explored in this study, some assertions will be made concerning the effects of particular frames on communities. Framing and structural pluralism will be reviewed separately followed by a section that examines the concept of the solution frame, a frame that is roughly defined as solving a problem within a news story (Coleman \& Corbitt, 2003).

This type of frame appears to have multiple designations, for example, "dominant frame," "institutional frame," and "master frame" (Ryan, 1991; Zavestoski, 2004). Ryan described the dominant frame as supporting the status quo, appearing natural, and excluding challenger positions (1991). Zavestoski and his colleagues described institutional framing as the actions of government agencies, public officials, and the media, who use framing strategies to gain support for their causes, creating the definition and acceptance of a particular version of a problem (2004). The last section of the 
literature review will build on the previous two while flushing out types of related frames.

In this thesis, framing is examined and grounded in the case study of the Umatilla Chemical Weapons Depot (UCWD) and incinerator located in Eastern Oregon. The study examines newspaper coverage of the depot and incinerator during the time prior to the decision to incinerate, specifically from January, 1994 to the end of December, 1998. The closest town to the incinerator is Hermiston, Oregon, and according to a website about cities, Hermiston had a population of 13,154 in 2000 and has a current population of 16,745 (2000 U.S. Census; 2010 U.S. Census).

In 1941, what was then known as the Umatilla Depot was established as a U.S. Army ordinance facility to store munitions, specifically chemical weapons. In 1945 the Depot's mission was extended to include the demolition of weapons. The Army built facilities within the boundaries of the depot and began storing chemical weapons in those facilities in 1962 (Umatilla Chemical Disposal Outreach Office, 2010). The depot, and subsequent incinerator, are located on 19,728 acres in Umatilla and Morrow counties three miles south of the Columbia River. A population of over 70,000 reside in Umatilla County, the area surrounding the facility. Three cities are in close proximity and downwind of the incinerator, Hermiston, Umatilla, and Stanfield. The city of Hermiston is one focus of this thesis and is thirteen miles by highway and five miles as the crow flies. 


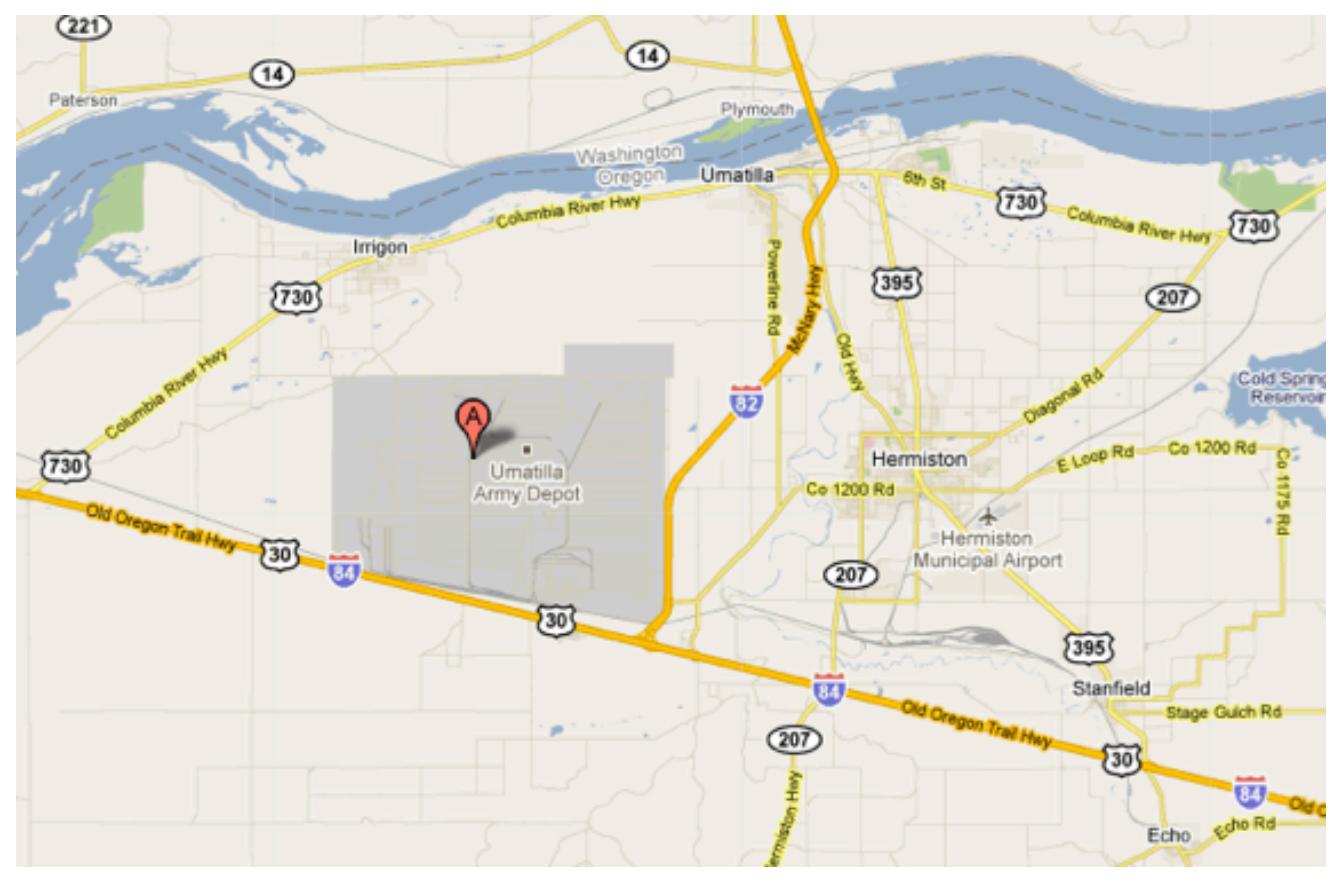

Figure 1. Map of area surrounding incinerator.

In accordance with public law 99-145, passed in 1986, the Department of Defense was directed to dispose of all its chemical weapons currently being stored in nine facilities across the United States by 2007 (Umatilla Chemical Weapons Depot Public Affairs Office, 2001). More than a tenth (3,717 tons) of the U.S. chemical stockpile is located in Oregon at the Umatilla Chemical Weapons Depot. In 1988, the Base Realignment and Closure Commission placed the UCWD on its closure list, thus requiring all weapons to be moved or destroyed (Department of Defense, 2004). The question of how to destroy the weapons became a story covered by both local and statewide newspapers. 


\section{Chapter 2. Literature Review}

In order to explore discourse in news accounts, I examined the literature in framing. The concept of framing is somewhat nebulous, in part due to the number of disciplines that use the term and the differences in definition. The term is also employed by lay people when talking about the news, often with very little knowledge of the different types of frames that may be operating. I am hopeful this study will make the concept of the solution frame more accessible.

\section{Framing}

The thesis is concerned with the concept of "solutions frames" and asks what types of frames are presented by the news media and how different frames may contribute to public knowledge of issues (Coleman \& Corbit, 2003). Solution frames, in their most basic sense, propose solutions to a problem of concern. Several of the studies reviewed will be from a compilation of such studies edited by Reese, Gandy, and Grant, titled "Framing Public Life: Perspectives on Media and Our Understanding of the Social World" (2003). This literature review connects framing with the theory of structural pluralism. The theory of structural pluralism generally concerns power differences in a community setting. However, when I discuss power I am referring to the ability of cultural and political groups in a community to determine their own destiny by expressing their opinions in local media, potentially influencing policies concerning community issues. For example, a local Native American tribe being described in a newspaper article as an 'influential group' that needs to considered in decisions about 
how to disposal of chemical weapons near their reservation. The definition of framing that will be used for this study is provided by Robert Entman:

To frame is to select some aspects of a perceived reality and make them more salient in a communicating text, in such a ways to promote a particular problem definition, casual interpretation, moral evaluation, and/or treatment recommendation. (1993, p. 52)

This definition is selected for two reasons. It is focused on the construction end of the framing interaction between media and publics, and it provides pieces that lend to examination of which aspects of a perceived reality are not selected. The construction of frames by those working in news media will be the main focus of this review. Due to the fragmented nature of the framing paradigm, wrapping the literature around a conceptual spool will be more difficult than with a flushed-out concept. Entman has expressed concerns about the "fractures" that communication scholars have revealed in framing research (1993, p. 51). For example, Entman sees a lack of consistency in definition of key terms and claims this makes building a comprehensible theory difficult. However, there are other researchers who feel this is not necessarily a negative direction for the field.

For example, D'Angelo counters that framing research has been advantageous to the field of communication by fostering the application of specific theories to increase the explication of a complex process (2002). Instead of one framing paradigm, D'Angelo identified three different research paradigms where framing can be placed. These paradigms are not mutually exclusive. The three "paradigmatic outlooks" are: cognitive (negotiation at the point of interaction between the frame and the individual's prior 
knowledge); constructionist (co-option by the journalist considering sponsors of the frame); and critical (domination of the framing process by hegemonic forces) (D'Angelo, 2002). However, since a frame can occupy multiple paradigms at once, these categories may cause confusion. A critical difference between the three outlooks is the autonomy of the audience.

One example of difference, according to D'Angelo, is that cognitivists and constructionists both support the position that individuals have agency and are not blindly following issues framed in the mass media. On the other hand, the critical position is that the news media occasionally include an alternative viewpoint while overwhelmingly producing a frame containing hegemonic values. On one level the study examines the frequency with which alternative viewpoints are included in new stories concerning a health threat.

For example, Reese viewed framing more as a bridge that connects various parts of the field, drawing together methodological perspectives from quantitative and qualitative domains (2007). Instead of the negative connotations of a scattered concept described by Entman, the organic nature of the field is viewed by Reese as a beneficial nexus of ideas revealing areas of overlap between different disciplinary viewpoints. As Reese asserts, an awareness of the combination of perspectives involved (i.e., cognitive, constructivist, and critical) keeps the "framing program from becoming too constricted and losing valuable cross-fertilization" (2007, p. 149). This research hybridization can lead to what D'Angelo referred to as "auxiliary hypotheses" or new openings for research (2002). This sounds like the "normal" process of scientific inquiry (evolution and 
accumulation of knowledge), yet this branching-out effect must be tempered with some direction to prevent the dilution of the field. Still, with such a complex process it is expected that many different theories would have heuristic value.

\section{Solution Frame}

The solution frame has been found in news stories describing problems that are a threat to publics, a solution to the problem is always provided (Bennett, 1988; Coleman \& Corbitt, 2003). For example, a news story detailing an oil spill off the coastline showing the oil company conducting a clean-up operation has a solution frame. The problem could have duration, providing for an ongoing community discussion. An example of duration would be a news story about an ongoing industrial chemical leak in a local river where the offending company has been fined by a state agency. It has been suggested that solution frames function to reassure communities, and are used in communities to prevent disruption or panic (Bennett, 1988; Coleman \& Corbitt, 2003). As Iyengar said, "ordinary citizens readily identify causes of national issues, and suggest treatment or solutions for social problems" (1991, p.120).

In this study, the citizens who identify solutions are the sources selected by the news reporter for attribution in news stories, and this information then enters the public dialogue. The solution frame is often accompanied by a time frame that is brief, providing a short dramatic introduction, problem, and clean conclusion through official solution. It has also been suggested that solution frames may be an effective way to promote public support for a product that will alleviate the problem (Coleman \& Corbitt, 
2003). For example, sending a press release about a termite infestation to the newspaper or television station to increase work for your pest control business would solve one type of problem.

\section{Episodic and Thematic Frames}

News practitioners have the power to frame issues in many interconnected and often overlapping ways. A particularly useful way to examine frames is the scope of their coverage. For example, are the frames short term or long term in their chronologic scope? A study by Iyengar categorized stories as being "episodic" or "thematic" in nature (1991). According to Iyengar, news frames that are episodic contain very little context surrounding the story. For example, they will not provide the history or events that may have led to a dramatic episode, or the long-term implications of a story (i.e., environmental damage, job loss, etc.). Thematic frames would provide these missing elements of the story. Thematic frames could show trends and conditions that may have contributed to a problem or risk, and thus provide information that may enable publics to make truly informed decisions concerning policies and actions that affect them. By excluding elements of the story and providing an official's reassuring quote, publics may be led to think all is well; when in reality those missing elements may point to a problem that concerns publics.

Episodic frames contain reassuring aspects that offer "normalization" (Bennett, 1988). The concept of "normalization" is explored by Bennett in his book, "News: The Politics of Illusion" (1988). According to Bennett, normalization is a journalistic 
tendency to "seek out the reassuring, authoritative voices of officials who normalize interpretations of the otherwise threatening and confusing event in the news" (1988, p. 24). In solution frames it is common for there to be one authoritative voice that serves this normalizing function. This could have the effect of leading publics to be complacent or remain inactive during times of danger, corruption, or deception by authorities, business leaders, or other members of publics who are violating their trust.

For example, if there was a chemical spill and one official is quoted as saying there is no danger, publics may not become concerned enough to investigate or seek safety. However, an environmental group may have a scientist who feels there is a longterm significant threat. The scientist may be ignored in an episodic and normalizing frame. These are times when the media need to serve that watchdog function (guarding the people's rights) and sound the alarm, letting the uninformed public know that things are not as they seem. This is not the only variety of omission that may take place. Shah, Domeke, and Wackman examined another type of exclusion of values, or seemingly strategic categorization within frames used by the news media (2004).

They suggested that if episodic singular solution frames are promoting dominant interests and blinding the people to other crucial choices, these frames may serve as hegemonic tools. For example, a problem is identified and a solution proposed by the official source, but if this solution has long-term consequences that are excluded because the frame is episodic, then publics may unknowingly support status quo policy decisions and suffer from the potential long-term consequences. The frames that are episodic and provide one solution are not only subtly providing the values held by the elites, but also 
excluding values or positions that may allow publics to question elite policy decisions. Frames that are episodic support the (profit driven) economic model, whereas a thematic frame may explore some of the potential future social costs or risks. In order to remain in power the elite must maintain the ability to subtly exclude challenger viewpoints, or as Chomsky said:

The smart way to keep people passive is to strictly limit the spectrum of acceptable opinion, but to allow very lively debate within that spectrum--even encourage the more critical and dissident views. That gives people the sense that there's free thinking going on, while all the time the presuppositions of the system are being reinforced by the limits put on the range of the debate. (Chomsky, 2002, p. 43)

Shah and colleagues identified two frames in particular, that are based on value sets: the ethical frame and the material frame. Ethical frames are found within stories focused on morals, basic principles, and rights. Material frames are evident in stories emphasizing practicality, economics, and pragmatics. They see journalists constructing stories based on one or both of the frames, while politicians and activists are battling over which values will be disseminated. Shah and his fellow researchers explored how valueframing can shape the interpretations of issues, encourage individuals to make attributions about politicians running for office, "apply social cognitions to policy evaluations" (2004, p. 228), and change their decision-making process.

As for which frames contribute to the ability of lay publics to make informed decisions, Shah and colleagues did not explore this area, but called on future researchers to do so. For example, it may be expected that frames emphasizing consumption of 
goods will be prevalent in the highly materialistic U.S. culture. As for the relation to solution frames, based on previous findings I expected that multiple-solution frames would contain more ethical values, and singular solution frames would contain more material values. However, this is not the line of inquiry for the current study. As, discussed earlier, some framing researchers are calling for a synthesis of framing concepts, while other researchers view the fragmented nature of framing as beneficial. Scheufele takes much of the work concerning framing and attempts to pull the studies together into a scheme for classifying research on framing as media effects (1999). Scheufele organizes framing research along two aspects: (a) type of frame analyzed (audience vs. media frames), and (b) operationalization of the frames (dependent or independent variable). In doing so Scheufele provides many insights into framing that are valuable to the present line of inquiry. He sees framing as an extension of agenda setting theory where the news media are telling publics what to think about. He looked not only at production of frames in his "media frames" analysis, but also dealt with audience reception of stories with "individual frames." For this study, I examined media frames as the dependent variable.

Scheufele examined Gerhard and Rucht's framing research where they synthesized much of the previous findings on framing into a single model with three types of framing: diagnostic framing (identifying a problem and attributing blame and causality), prognostic framing (specifying what needs to be done), and motivational framing (a call for corrective action) (1999). This research can be applied to many news 
stories concerning the environment or public health, such as the controversy surrounding the now banned pesticide dichlorodiphenyltrichloroethane (DDT).

For example, a news story where the pesticide DDT is being described by a scientist could be a diagnostic frame, and a federal official saying that DDT will have restricted use could be a prognostic frame. A motivational frame may be present in a solution frame with multiple solutions. An example of the dominant position would be an activist group calling for a protest against pesticide use, and a local citizen's quote expressing concern about DDT. These categories provide a step in the task toward explicating different frames. In a singular solution frame the first two types are present in one frame, the diagnostic and prognostic; and in the plural solution frame, multiple prognoses would be present, including (potentially) a motivational frame (Robertson, unpublished manuscript, 2001). Multiple prognoses would provide more information for those deciding policy as well as for those participating in public discussion.

When Gamson and colleagues wrote of frames, they described "symbolic devices" as part of a clustering that contained other devices such as metaphors and moral appeals. Gamson called these clusters "packages" (1989). Packages have an internal structure and the nucleus of this structure is an idea that makes sense of relevant events and implies what is at issue (Gamson, 1989). In the case of policy decisions, such as deciding which disposal policy/technology to use for the weapons at Umatilla, there is a form of competition over what packages will be used or emphasized in order to control which constructed frame will prevail (Gamson \& Modigliani, 1989). The media take on a primary role in this contest, as they are central in framing issues. For example, framing 
by newspapers may emphasize the differences between two technologies for weapons incineration, while ignoring other technologies or omitting ideas provided by challenger groups.

\section{Frame Manipulation}

The evidence for frame manipulation can be difficult to ascertain, due to the subtlety of symbolic devices (Gamson \& Modigliani, 1989). Gamson and Modigliani made it clear that frames are not to be mistaken for positions against or for a particular policy. For example, while a solution may be the use of petroleum to avert an energy crisis, there will be ample room for disagreement about what type of extraction process will be used, and a challenger group may advocate alternative energy. Issues can be framed in themes that reflect cultural values or myths, such as societal commitment to technological solutions and economic progress (Gamson \& Modigliani, 1989).

For example, the frame could be one of extreme danger, in this case, a rush to use chemical dispersants on an oil spill before the dispersants are tested for toxicity or before other clean-up methods could be explored. The impending threat of the oil reaching shore is further impetus for a hurried policy decision. The problem within the story could be that "the oil is advancing to the coast," and by inclusion or exclusion, the frame can determine if alternative cleanup positions are relevant. Frames can be infused with cultural values that may cause certain solutions to resonate with viewers more so than others. One such value could be individualism, which is championed in American culture and appears in many frames (Hofstede, 1980). For example, the "right" to make a living, 
in this case, fishing in the oil impacted waters. A solution linked to this value-laden frame may be popular with certain groups, and receive more support in the public forum. The petroleum company involved would likely be a heavily invested sponsor of solution frames in this scenario. For example, the petroleum company may promote a news story focused on how the company solution of chemical dispersant is eliminating the threat to fishing and wildlife.

\section{Sponsor Activities and Media Practices}

Some packages have greater significance for the audience due to their ideas connected to the dominant culture. Gamson and Modigliani identified two other broad classes of package determinants: Sponsor Activities and Media Practices. Sponsor activities are tangible activities such as speech making, public relations campaigns, and the filing of legal briefs (Gamson \& Modigliani, 1989). For example, if a nuclear reactor had a meltdown, frame sponsors would be the company running the reactor and the state and federal authorities. The power company responsible would likely be engaged in activities such as PR campaigns, legal briefs, expert testimony and interviews in order to assure publics of their safety and possibly determine the cause of the problem.

A frame containing various packages that sponsors may support could be the suppression of risk through economically efficient technology in cleanup. This frame carries three interwoven packages constituting a story supporting the dominant position or status quo. The packages could be risk avoidance, economic efficiency, and cultural reverence of technology. Using the oil spill scenario, a statement may contain phrases 
such as, "we (oil company) are dealing with the spill, we are using the best chemical dispersant available to mankind, which will mitigate the harm to local fishing business," or, "the safety of workers, publics and the environment are paramount to the success of the oil company's clean up mission." Frames providing more than one solution, including alternative viewpoints, may have asserted that studies exist showing the dispersant is toxic. However, more often the solution frame will include officials making statements that portray alternatives as cost prohibitive or threatening business interests. These wealthy frame sponsors often have greater access to the reporter constructing the news story.

Access to reporters often is related to media practices. For example, the newspaper workers and the professionals working for these sponsors often understand each other much better than challengers supporting an alternative framing (Gamson \& Modigliani, 1989). This understanding between the newspaper workers and professional media consultant or savvy politicians can lead to their position being accepted, while the challenger's position (non-dominant alternative view) is required to provide a greater level of proof. This is an aspect of the media practices determinant, whereby reporters "unconsciously" trust a solution presented to them by official channels (Gamson \& Modigliani, 1989, p. 7). This trust may be formed as a result of repeated interactions between reporter and sources such as a government official, private public relations practitioners, or media specialists. For example, if the reporter has known of the politician for a long period of time, his story may not receive as much editorial scrutiny as the environmental group from out of state. Public relations specialists are skilled in 
crafting messages and in packaging stories in a way that may lessen the workload for a busy reporter, while challenger groups are often under-trained. Reporting two sides of the story (or simply having two sources), which Gamson and Modigliani call the "balancing norm" is not the same as including a truly alternative position $(1989$, p. 8$)$.

\section{Balancing Norm}

Gamson and Modigliani found that while there is a balancing norm with many frames, the challenger is rarely included "even when no other alternative is available" (Gamson \& Modigliani, 1989). The idea of a balancing norm is related to the concept of "normalization" explored by Bennett as noted earlier in this chapter. According to Bennett, normalization is a journalistic tendency to, "seek out the reassuring, authoritative voices of officials who normalize interpretations of the otherwise threatening and confusing event in the news" (1988, p. 24). Gamson and Modigliani described a normalizing frame as a formula that is repeated nightly on the evening news with a warning of a danger or risk, an explanation, and officials managing the risk (1989). For example, a forest fire occurs and officials are quoted talking about the planes used or how many acres were burnt. An alternative voice talking about forest service policy contributing to excess underbrush as fuel for fires is unlikely to be included, but would provide useful information.

This type of frame is even referred to as an adventure tale in the tradition of “disaster averted" films where officials use technology to bring, for example, a risky situation under control (Gamson \& Modigliani, 1989). The narrative structure along with 
a single official response is still present. The problem is identified, there is rising action as all of the representatives of state talk of the risk, while private interests (acting as the hero) step in and provide a remedy for the problem, acting as the narrative's falling action and meticulous conclusion. Gamson and Modigliani argued that narrative structure possesses cultural resonance due to the folk tales, myths, and stories that are part of the audience's culture. Gamson and Modigliani conclude that the audience would have to go beyond national media outlets to encounter truly alternative frames (1989). For example, independent online media, international media outlets such as LinkTV, or individual independent citizen journalists operating via social media websites.

Alternative frames may provide information that in turn could change public opinion or enhance public discussion. If other challenger groups had a voice in dominant solution frames, they would potentially have more power to influence decisions made in their communities. Then the frame would be a pluralistic frame. The more groups that have power in a community, the more pluralistic the community. For example, a community with low levels of pluralism will have fewer groups with power; with few players dominating the framing. For example, players may be the mayor, business interests and the dominant church. In a community with higher levels of pluralism, there is a diversity of players such as various ethnic groups, environmental groups, or gay and lesbian advocates.

So far, I have discussed framing, particularly solution frames and how they are structured. I have proposed that solution frames are not separate from episodic and thematic framing, and that a solution frame will either have episodic or thematic scope 
embedded in the same story. I have also related normalization to solution frames with an episodic scope, whereby publics are reassured that the problem detailed in a story is being alleviated by the dominant or official solution and there is little history or implications discussed. I detailed several values that can be contained in frames that may enable those frames to manipulate the publics' position concerning a particular policy decision, and which groups or individuals may be sponsoring these frames. I described how some groups or individuals are often more successful in gaining access to reporters and framing events to their liking. I will now review the literature concerning power of different groups within communities.

\section{STRUCTURAL PLURALISM}

Structural pluralism arises from the diversity of a community. In the most basic sense, if a community has a high level of structural pluralism, many different groups will have a voice in community decision making, whereas a community with low structural pluralism will have a few dominant groups that push the status quo on other groups. Specifically, in the context of mass media research, structural pluralism has been defined by P. J. Tichenor and colleagues as "the degree of differentiation in the social system along institutional and specialized interest group lines, in a way that determines the potential sources of organized social power. (as cited in Hindman, Littlefield, Preston, \& Neumann, 1999, p. 250)" Concepts within structural pluralism include social and cultural pluralism, political pluralism, and elitism. I examined the literature of the field concerning structural pluralism, beginning with a look at some of the measures of 
diversity used by researchers, followed by a brief examination of several studies looking at news aspects of structural pluralism.

One of the underlying ideas within pluralism concerns the positive value of public dialogue and the diversity of information and ideas discussed within a community. In a democracy, it is essential for citizens to be provided with diverse information and a variety of opinions in order to make an honestly informed decision about which policy or politician to support or oppose (Robertson, unpublished manuscript, 2001). Another way to imagine pluralism is whether a community has a diversity of power, embodied in heterogeneous and horizontal power groupings, in contrast to a homogenous hierarchical power unit. A real life example of this could be the rotation of power in a large city with a great diversity of groups that are able to have their voices heard, compared to a smaller homogenous city that has one group that continually dominates the decision-making processes and public dialogue.

Tichenor and colleagues have examined mass media in ways that show that differences in structural pluralism or shared power influence news coverage. The current line of inquiry will ask whether the use of particular frames in news coverage serves to reinforce the absence of structural pluralism, or serves to open debate and allow structural pluralism to flourish. Many scholars question whether pluralism is a static state of power or an ongoing dynamic process. It would appear that pluralism may appear static at times but is more of a process because it is not taking place in isolation and is influenced by changes in community structures. Pluralism initially may take the form of competition between various interests vying for power. However, after some period of time these 
conflicts (e.g., elections, frame contests, or policy formations) may settle into a more balanced distribution of social and political resources.

Measures of structural pluralism originally consisted of such items as the population of the city, education levels of the residents, income and employment of residents, types of businesses, and similar demographic data often obtained via the U.S. Census (Jeffres, Cutietta, Sekerka, \& Jae-Won, 2000). More recently, several other measures have been used; for example, the number or variations of religious denominations, percentage of minority children in school, ratios of Black-White home ownership, and other ethnic-based measures (Jeffres et al., 2000). Methods have varied from the above-mentioned use of census data, to surveys and content analysis (Coleman \& Corbitt, 2003; Demers, 1998; Hindman, Littlefield, Preston, \& Neumann, 1999; Jeffres, Cutietta, Sekerka, \& Jae-Won, 2000). The studies focus on one channel of communication (i.e., newspapers) as the context, which could be expanded to include television and the internet. For the current study, measures of pluralism will include population size, educational attainment level, income, and race.

The comprehensive study conducted by Jeffres and three fellow researchers examined newspapers and pluralism, and also examined a range of previous studies with similar lines of inquiry (2000). Demers and Hindman's works are notable for the additional measures concerned with ethnicity and minority representation. For example, across all media markets in which minority-owned television stations operated between 1999 and 2006, the number of minority-owned television stations dropped by 27 percent (Stuke \& Grunes, 2009). According to Jeffres and colleagues, newspapers in the 
community with a greater degree of structural pluralism will tend to report in a manner that supports debate of issues, while those in a more homogenous community will report in a manner that promotes consensus or allegiance to the status quo (2000). This further exclusion of potential alternative viewpoints may lead to fewer frames containing multiple solutions for problems or risks.

Jeffres and colleagues cite previous research to make a distinction between heterogeneity and structural pluralism. The difference in a heterogeneous community is that the various groups would share social institutions, yet in a truly pluralistic society the various groups would posses their own social institutions (Jeffres et al., 2000). For example, churches, schools, newspapers, and coalitions of businesses and/or cultural groups could be social institutions providing power. Another distinction made by Jeffres and his colleagues is between measure of diversity, pluralism, and "life cycle" (2000). Diversity refers to differences in gender, race, and language use; pluralism refers to education, occupation, and household income; and life cycle refers to age, household size, and marital status (Jeffres, et al., 2000).

Turning to the role of news organizations, David K. Demers takes to task the conventional wisdom that newspapers become less vigorous in their editorial actions as they take on corporate characteristics (1998). He also challenged the position that the support of dominant values and elitist goals by editors increases as the media organization becomes larger. Demers attempted to take a different methodological direction in testing this position. He noted that much of the previous research is based on content analysis, and he selected survey as his method. Demers conducted a survey of 
news sources, specifically mayors and police chiefs (1998). He asserted that, contrary to Neo-Marxist positions, corporate newspapers will be more "critical" in their issue analysis because they are located in more pluralistic communities and are "insulated from local political pressures" (Demers, 1998, p. 572). Both Demers and Jeffres are limited in their studies in that they are measuring the perception of the sources or the editors, instead of or in concert with actual content or reports in the papers. Jeffres' assertions that the distance from a larger metropolitan area could have an effect on the insulation of small town newspapers. For example, the farther from a large metropolitan center a newspaper is, the greater the pressure from local political entities to accept the status quo perspective.

Jeffres contended that race may not be an important factor, asserting that the "dispersion of power among social groups in not equivalent to the level of ethnic and racial diversity in a society" $(2000$, p. 160$)$. Hindman disagreed, claiming that this view is in line with an assimilation-acculturation model where the less powerful groups lose traditional cultural traits and internalize the new cultural traits (1999). This form of naiveliberalism associated with the "melting-pot" metaphor is proving to be less valid, as numerous cultural enclaves persist and provide numerous forms of social power for members.

This form of liberalism is a synonym for what is an assimilationist view, which doesn't recognize the value of cultural identity and seeks to strip away cultural differences and replace them with dominant American cultural values. Hindman argued that this model, instead of being supported by pluralism, is rejected because ethnic groups 
can remain distinct within the political system. This is similar to a venn diagram with a small area of overlap where the minority ethnic group interacts with the larger culture while still remaining a unique entity. These groups can retain their cultural heritage while also participating in public discussion and policy decisions. In other words, there is no 'melting' of cultural groups within structural pluralism, but but a respect for unique ethnic identities along with the social and political power required to have a voice within the community. Ethnic diversity is not the same as political diversity. Where problems of political representation exist, ethnic diversity of the community is not reflected in the political arena. For example, migrant workers and unregistered voters may not have as much access or voice, as wealthy business owners.

\section{Pluralism and Communities}

The foundational piece in the field of pluralism by Tichenor and colleagues examined consensus reporting styles and conflictual reporting styles (1980). The key aspect of "structural pluralism" according to the authors, is tied to the distribution of power in a community. Power is held to be more widely distributed and decentralized in larger heterogeneous communities than in smaller homogenous communities. For example, some of Tichenor's measures are the number of educational centers and volunteer groups per capita (1980). Another way to think of this concept is the greater the number of differing voices or perspectives allowed to be heard in a community, the greater the chances of those groups having power and the greater the degree of structural 
pluralism of that community. Two key Tichenor terms used by Jeffres et al. are the "distribution control process" (DCP) and the "feedback control process" (FCP).

Distribution control process refers to newspapers in homogenous communities that engage in status quo reporting and avoid conflict, while feedback control process is the process of a newspaper in a heterogeneous community bringing out conflicting viewpoints so that issues can be "solved." Jeffres and his fellow researchers explicate three related concepts: size, structural pluralism, and diversity. Size refers to the population size of the community under investigation. Pluralism is "social differentiation" or alternative voices having power, where as diversity is the heterogeneity or groups without said power. Jeffres et al. view Tichenor's theory applying to newspapers in two ways: (a) There is more public conflict in a heterogeneous environment and thus, reporters naturally report such conflict as "functional" for the larger system, and (b) journalists in more pluralistic environments are more likely to "see" more conflicts and to perceive more differentiated distribution of power.

The work of Jeffres et al. relates to the concept of solution frames in several ways. If the solution identified to deal with the perceived risk is only the dominant one, then the frame is part of a distribution control process because the frame avoids exposing conflict, supports an appearance of consensus, and would likely be used in a homogenous community. However, if the frame identifies multiple solutions, including challenger positions, then the frame is part of a feedback control process because it brings out different viewpoints for discussion and supports heterogeneity in the community. 


\section{Media Dependency}

Especially in today's world of information abundance, Lippmann's pioneering work "The World Outside and the Pictures in Our Heads" provides insight into the concept of framing in general (1922). Lippmann pointed out that we really have little idea what is occurring unless we have direct physical contact with the occurrence. We have abstract ideas that are received from many channels, which meld together into what Lippmann called a "mental image of the event" (1922). He emphasized the point that receiving even one fictitious external fact could produce an inaccurate mental image (Lippmann, 1922). Lippmann called the area between humans and the natural world the “pseudo-environments.” This dynamic ether-like pseudo-environment is filled with representations, both accurate and inaccurate, created by the mass media through the increasingly pervasive dissemination. Interpersonal channels and prior experiences also influence perception and judgments. Mediated stories help create what Lippmann called "pictures in our heads" (1922). This begs the question of how much influence is held by the channels suppling the information, and to what extent publics rely on, and depend on mass mediated information (Carregee \& Roefs, 2004; Hertog \& McLeod, 2003; Nelson \& Willey, 2003). If we see the "general" public as not being dependent on the mass media for information, then they either must get information from interpersonal channels or from direct experience.

Assuming that publics form judgments based on information from the pseudoenvironment, we must examine research exploring the relationship of publics to the media and information. A foundational piece on media and dependency by Sandra J. 
Ball-Rokeach and Melvin L. DeFleur will provide a beginning. Ball-Rokeach and DeFleur examined the dependency of individuals and society on mass media, and the potential effects of such dependency (1976). They point out that their analysis acknowledges that the media and audience variables must be examined concurrently with societal variables. By examining all three variables, "individually, interactively, and systematically," we can better comprehend mass media effects (Ball-Rokeach and DeFleur, 1976, p. 5). These effects are key to understanding how media messages can influence audience attitudes, beliefs, and even actions. Ball-Rokeach and DeFleur identified three needs that makes publics dependent on the mass media: (1) the need to understand one's world, (2) the need to act meaningfully and effectively in that world, and (3) the need for an escape from life's daily struggles (1976).

Ball-Rokeach and DeFleur argued that prior knowledge is a key filter for receiving information. For example, when science is involved in an issue, the majority of the audience must rely on experts to explain technical issues. This arguably increases their dependence on news media. This has often been the situation with environmental risks or disasters. In the case of scientific uncertainty, when people become aware of a risk, they wish to reduce their uncertainty. Ball-Rokeach and DeFleur called this cognitive effect, "resolution of ambiguity" (p. 9). How people are able to resolve this ambiguity is related to what information they receive, which may be filtered and framed by mass media.

Ball-Rokeach and DeFleur identified fear and anxiety as two "affective effects" that influence dependency. It is plausible that if someone is exposed to an issue that has a 
cognitive effect of ambiguity, the effect would be fear (affect); or as Ball-Rokeach and DeFleur stated, "It is difficult to imagine the cognitive effect...without accompanying affective effects" (1976, p. 15). When the issue being framed is a risk to the health of the audience, and if they have little knowledge of or experience with the risk, fear and anxiety could easily ensue. The audience may be highly dependent on "expert" opinions expressed in news stories. A news story may generate fear, and this fear could be reduced by the introduction of a solution assuring the audience that they are relatively safe.

\section{Framing and Power}

The power to express one's opinion within the channels that are used to disseminate messages, such as mass media, is of interest to this line of inquiry. Some of the reasons given for a lack of research into the ways in which framing and frames may allocate power are: the problems with a conceptual definition; minimal focus on frame sponsorship; a failure to examine framing contests on a macro-societal level; and the limited framing research on media effects (Carregee \& Roefs, 2004). Another question concerning power is who has the power to frame: sponsors (government officials, social activists, business owners), reporters, and/or the audience. Sponsors may promote frames and the reporters construct them based on a multitude of factors, including cultural values, journalistic routines, institutional pressures, economic imperatives, community values, and ideology of the parent company. The audiences (and reporters to a degree) process these frames based on another group of factors such as experience with the topic, cultural values, public opinion, perceived salience, and even mood or emotions involved. 
According to Bennett there are two models of power in relation to the news (1988). One is the ideal vision and one is the practice at large. The "ideal model" is the Jeffersonian idea of the power resting with the people, the leaders representing the views of those people, and the media serving a watchdog function. However, the model that appears to operate most of the time is far different. The model commonly employed may resemble the "propaganda model" introduced by Herman and Chomsky (1988).

This model acknowledges dramatic differences in wealth and power of those attempting to gain access to mass media. Chomsky and Herman asserted that powerful interests are able to filter which news goes to print, favor government and dominant private interests, and marginalize dissenting or alternative viewpoints. There are five filters identified by Chomsky and Herman: (1) The size, concentrated ownership, owner wealth, and profit orientation of the dominant mass-media firms, (2) advertising as the primary income source of the mass media, (3) the reliance of the media on information provided by government, business, and experts funded and approved by these primary sources and agents of power, (4) flak as a means of disciplining the media, and (5) anticommunism as a national religion and control mechanism.

Many leaders are working hand-in-hand with corporations to reduce regulation and increase financial profit. Politicians support corporations by pushing specific agendas and promoting "progress" through policies that would otherwise be rejected by publics. As Bennett succinctly put it: 
As numerous examples from the book indicated, leaders have usurped enormous amounts of political power and reduced popular control over the political system by using the media to generate support, compliance, and just plain confusion among publics. The media thus reinforce the legitimacy of power from above while defusing the demands for power from below. The roles of elites and the media in this power structure clearly relegate the power of the people to the bottom of the heap. The public is exposed to powerful persuasive messages from above and is unable to communicate meaningfully through the media in response to those messages. (1988, pp. 178-179)

This is a passive audience model which puts responsibility on those constructing the news. There are times when publics can influence the frames being developed, such as protests demanding coverage, but this communication is sporadic while news media framing is a daily event. The quote above illuminates how influential the news media can be. In an ideal world all parties would have equal opportunity to communicate concerns or ideas. German philosopher Jurgen Habermas is foundational, discussing the "public sphere" where discourse takes shape.

Habermas discussed the concept of public sphere, an idea similar to Lippmann's pseudo environment (1962). This is similar to a public forum with access to information and a voice guaranteed to all. Researcher Edward Herman described a fundamental shift in values within the public sphere. Herman said space (i.e. physical, textual, and mental), within the public sphere is being taken over and converted into space that is used solely for profit. For example, beverage companies lobbied to put billboards in outer space 
selling soda pop, converting the sky to an advertising area. Herman asserted that advertisers are the major actors in promoting this takeover. Herman saw public space being privatized, and the values that are being emphasized are not in the publics' best interests. For example, advertising promotes consumption rather than solving real problems, such as poverty, environmental degradation, war, etc.

Herman pointed out that the media conglomerates' primary focus, when obtaining use of public space, is to put it to "best economic use" which can be translated into squeezing that space for every drop of possible profit with little concern about the social and environmental consequences. Herman provided evidence showing that public space appropriated is often local public programming, which is replaced by commercial programming that advertisers find more profitable. This invasive domination of broadcasting space leaves little room or opportunity for alternative views or programming. Due to the ownership of mainstream media being reduced to ten corporations (AOL/Time Warner, AT\&T, GE, News Corporation (Rupert Murdoch), Viacom Inc., Bertelsmann, Walt Disney Co., Vivendi Universal, Liberty Media Corporation, and Sony) and the increasing market saturation of these large players, controversial or unprofitable views are silenced (Miller, 2002). For example, Herman asserted that this leads to fragmentation and "niche-filling" by public programming, which is doing little to stem the commercial/capitalistic tide (1998).

Herman used the economic theory of "externalities" to examine this reduction in media ownership in the U.S., and then showed this same model going global with increased deregulation (1998). Externalities are costs and benefits that are not accounted 
for in the present economic model (market pricing system), or "a benefit or cost of a market process that does not accrue to the source but affects others" (1998, p. 126). For example, while a logging company captures the profit from selling the wood, the costs of clearing landslides and environmental costs resulting from upland clear-cutting are covered by tax dollars or private landowners. External costs may be excluded from news frames, especially if they are long-term health or environmental.

In the realm of broadcasting and print news, Herman argued convincingly that public programming accrues positive externalities and much entertainment (and increasingly news) feature sex and violence, "making people more fearful insecure and violence-prone" (1998, p. 126). In the same way the market pricing system is failing to capture these external costs, singular solution frames are failing to include a thematic and comprehensive view of the problem and the costs of the prescribed solution. It is not a direct comparison, yet the alternative or challenger viewpoints often shed light on "externalities" showing how there may be costs that should be considered in policy decisions or solutions.

Herman gave some stinging rebuttals to critics that claim the audience is "coproducing" the media materials, by pointing out shifts in values and utilization of public space. He used a passive audience model, seeing the average citizen as unaware of how she is being democratically hobbled by myopic news. If audience members were more aware of elements that are missing from a dominant frame they may act to obtain alternative viewpoints or uncover externalities. However, as the amount of time people 
spend consuming mass media messages increases and the ownership of said media decreases, obtaining excluded information becomes more challenging.

Lay people with non-academic knowledge concerning news media construction may have minimal understanding of what is occurring behind the scenes of a frame, in part because the frame conceals the larger powers at work behind the news (Reese, 2003). According to Antonio Gramsci, hegemony is not only the domination of one group over another, but an implicit system of domination whereby the oppressed unknowingly internalize the values used by the oppressor to remain in a dominant position (1971). Hegemony is committed by the dominant power and unconsciously perpetuated by the oppressed. Therefore, the citizens in a true democracy need access to as much pertinent information as possible, but if they don't know information is missing how, can they be involved in policy decisions?

\section{RISK}

Mary Douglas is a trailblazer in the area of risk assessment and her work can be applied in the current context. In her book "Risk and Culture: An Essay on the Selection of Technological and Environmental Dangers", she covered many aspects that are pertinent to the current study (1982). Douglas grouped risk into four categories at the level of public policy: (1) Foreign affairs. This includes risk of foreign attack or encroachment, war, and loss of influence, prestige, and power; (2) Crime. This refers to internal collapse, failure of law and order, and violence versus white collar crime; (3) 
Pollution. This includes abuse of technology, and fears for the environment; and (4) Economic failure. This is loss of prosperity (1982).

As Douglas noted, people worry about different risks, and certain dangers are increasing (1982). Douglas said, "The perils of nuclear wastes and carcinogenic chemicals are not figments of the imagination. Different groups give exposure to toxic chemicals of vastly different significance. Fear of risk...has something to do with knowledge" (1982, p. 2). If the community is aware of a risk but does not have sufficient knowledge of, for example, the science involved, it is at the mercy of those channels providing information. Power that can influence attempts to frame a risk, which can mean that public information is limited in scope. For example, a risk may exist between two communities that have differing levels of pluralism. In these communities the groups that have power to frame the risk define the boundaries of debate concerning policy or risk remediation.

\section{Framing and Risk}

Recall that Dietram Scheufele took much of the work concerning framing and media effects and attempted to pull it together into a scheme for classifying research on framing (1999). In doing so Scheufele provided many insights into framing that are valuable to the present line of inquiry. He looked not only at production of frames in his analysis, but also dealt with audience reception of frames. Scheufele cited Entman to show how media frames can provide schema for interpretation of risks: "To frame is to select some aspects of a perceived reality and make them more salient in a 
communicating text, in such a way as to promote a particular problem definition, casual interpretation, moral evaluation, and/or treatment recommendation" (1999, p. 107).

After reviewing this and other related literature a model was created (see below). The model attempts to synthesize some of the episodic framing finding and information on solution frames (Coleman \& Corbitt, 2003; Iyengar, 1991). This model is an artist rendering and has no link to any data or actual news stories. The large pyramid represents a theoretical news story with a thematic scope. A pyramid was selected due to the resemblance to a profile of a rising plot line, climatic action at the peak, followed by falling action as the problem is solved. The smaller shapes that resemble the sails of a boat represent theoretical news stories with episodic frames. Their size and shape represent a short time frame, with the quick rising action, solution, and little to no falling action or implications.

The y axis represents level of threat from the risk described in a theoretical news story, and the $\mathrm{x}$ axis represents the scope of time covered in the theoretical news story. The model shows some of the context and potential implications that are ignored in an episodic frame as well as showing the basic narrative structure of a singular solution frame. Bennett described a macro perspective of a cycle that is similar to the microstructure of the singular solution frame (1988). Bennett called this cycle the "crisis cycle" and claimed that is it is portrayed in the news as, "classic dramatic fare with rising action, falling action, sharply drawn characters" and plot resolutions provided by officials (1988, p. 24). 


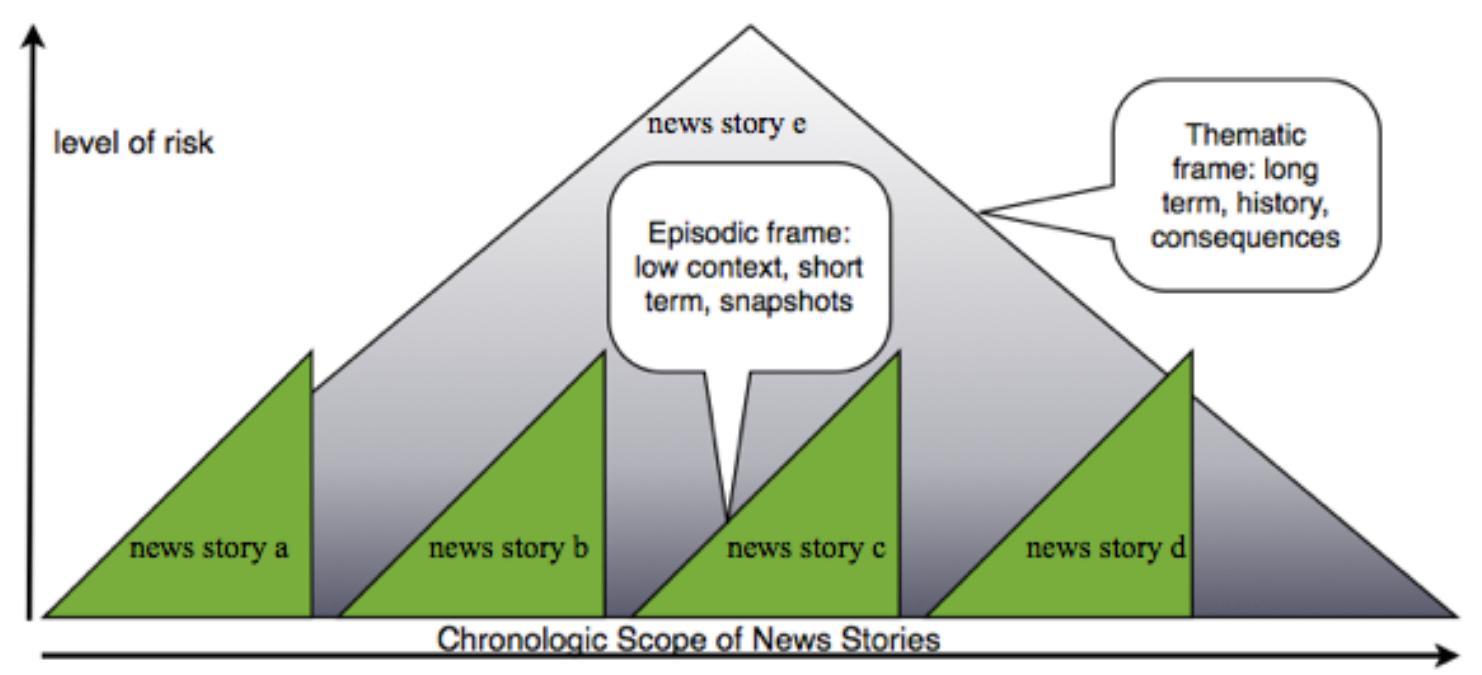

Figure 2. Episodic and Thematic frame Illustration.

In Figure 3, I show how a reporter might construct a story concerning a problem or risk. The figure represents a flow chart of the two frames, even though the model appears to begin with the reporter there are pre-reporter actions which are outside the scope of the proposed study. The reporter obtains information concerning the issue from a variety of sources, and then writes (frames) a story which is published in the newspaper. The interpersonal channel text box in the center is in reference to the the other source of information available to publics. Recall that, Jin Yang and Gerald Stone found that people rely on the mass media for about 80 percent of their information and rely on interpersonal communication for the other 20 percent; and those that are the interpersonal information providers are conduits for the same media messages (Yang \& Stone, 2003).

This model assumes an active public. The interpersonal channels in the center represent opinion leaders researching the issue, potentially supplying information to less informed publics. The publics exposed to the pluralistic frame with multiple solutions 
should be better prepared to participate in the policy discussion taking place in the community than those exposed to the (single) solution frame. The arrows that flow out of the large text box at the base of the figure ("informed...") are present to illustrate the potential of information in the community to cycle back to the reporter. 


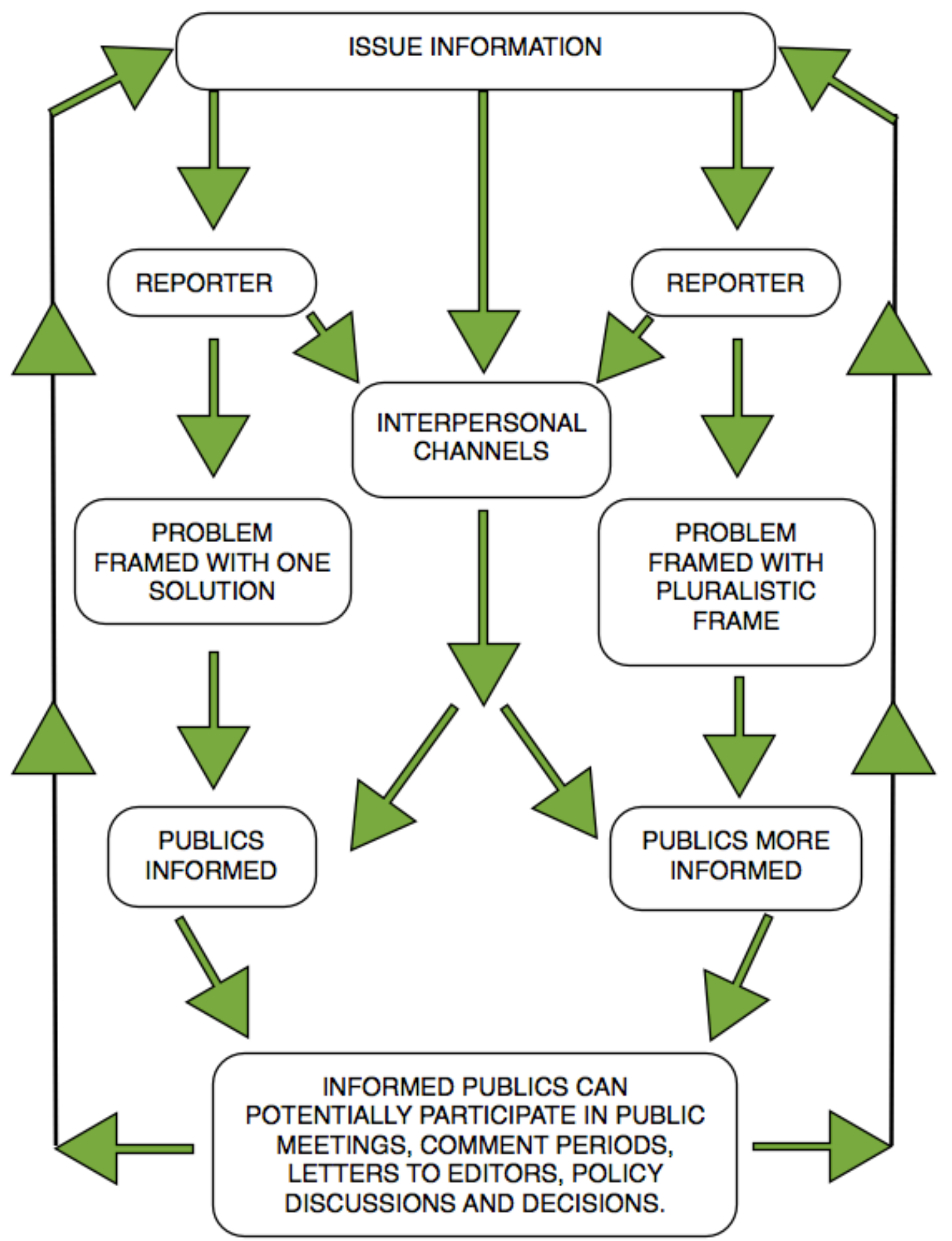

Figure 3. Information flow chart from reporter to audience. 


\section{Chapter 3. Case Study Background}

As stated earlier, the study is concerned with the Umatilla Chemical Weapons Depot (UCWD) and related incinerator located in Eastern Oregon. The study examines newspaper coverage of the depot during the period of time prior to the decision to incinerate, from the beginning of January, 1994, to the end of December, 1998. As noted in the introduction, the facility was built to house weapons following World War II, and a decision was made in 1986 to destroy the weapons.

The renamed Umatilla Chemical Agent Disposal Facility (UMCDF) was completed in 2001 and the Army began incinerating weapons in 2004. As of May 1, 2011 the Army has incinerated 75 percent of the original 7.4 million pound stockpile. Many of the challenger groups spent years in their efforts to prevent the incinerator from being built and going into operation. The tactics consisted of attending public meetings, communicating with the media, and suing in the courts. One activist that was mentioned in numerous articles is Karyn Jones, director of the challenger group GASP and head of the governor's Citizens Advisory Committee on Demilitarization (CACD). She pointed out that when the state approved the incinerator in 1997, the Army claimed all weapons would be destroyed by 2003 (Oregonian, 2004). The overall cost of disposal has grown to $\$ 2$ billion. The incinerator is burning tons of hazardous material, over 2,850 tons have been incinerated as of May, 2011.

The agents being burned were originally designed to incapacitate humans during warfare. The result of incineration is the release of toxics into the air very close to the surrounding community of Hermiston. Studies have found dioxins present in the dust and 
soil surrounding trash incinerators, which means it is most likely in the groundwater due to leeching from the soil (Bumb, 1980). If regular trash is producing dioxin, it is not surprising activists like Karyn Jones who are concerned about the dioxins released when burning nerve agents. Dioxin has an estimated half-life of 10 years in the soil, and airborne dioxins can travel long distances before landing on plants, humans, and bodies of water (Nadakavukaren, 2000). Dioxins are teratogens: chemicals that causes birth defects such as structural deformities (Nadakavukaren, 2000).

If the dioxins land in agricultural areas the substance could enter the food chain through consumption of the resulting produce. Improper immune system function, cancer, and even fetal toxicity are other effects of dioxin on lab animals as well as humans (Nadakavukaren, 2000). It is understandable why the incinerator is considered a risk after reading the literature detailing how incineration can result in toxic dioxin residing in the surrounding air, surface/ground water, and the food chain.

In September 2002, the Army conducted a "high-temperature mini-burn" in a pilot incinerator located at the Umatilla site. The burn released "unacceptable levels" of lead and chromium as well as mercury, arsenic, and heavy metals into the air; all of these compounds are carcinogenic (Sierra Club, and UMCD, 2002). The Army responded by saying that they would re-calibrate the instruments (UMCD public relations, 2002). 


\section{Chapter 4. Conceptualizations and Definitions}

The two frames that will be examined in the study are the solution frame and the pluralistic frame. The solution frame is commonly defined as one that poses a problem and then identifies a solution. Within the literature this type of frame is the "dominant frame," "institutional frame" and "master frame" (Ryan, 1991; Zavestoski, 2004). Ryan described the dominant frame as supporting the status quo, as appearing natural, and excluding challenger positions (1991). Zavestoski and his colleagues described institutional framing as the actions of government agencies, public officials, and the media using framing strategies to gain support for their cause, creating the definition and acceptance of a particular version of a problem or risk (2004).

Officials identify a problem, define the problem and prescribe a solution. The prescribe solution can be the policy piece of a framing equation. This sounds very similar to the solution frame, except it is not defined by having one solution and the normalizing aspect Bennett described is not explored (1988). A distinction between frames with one proposed solution and those with two or more solutions will be made in the current study. If a frame is a paraphrase of the original single solution it will not be considered to have more than one solution.

The pluralistic frame will be identified as having more than one solution to the problem, not only because the numeric count is more than one. The reason frames with multiple solutions will be considered pluralistic is more groups appear to have the power to have their voice heard in the frame. I argue this gives them some form of power in the community. Recall that research has shown that often the additional solution is offered by 
a challenger (Ryan, 1991). If the newspaper is playing the gatekeeper at the entrance to the public sphere or pseudo-environment where publics dialogue, then other groups in the community must have access to the story in order to have a voice concerning issues of importance (Habermas, 1962; Lippman, 1922). In order to address the hypotheses below, I must define and measure key terms such as "solution frame," "pluralistic frame," “episodic frame," and "thematic frame." Below I address the definitions.

\section{Definitions}

Framing: Recall that the literature review reveals that "frame packages" often include solutions to problems. An example of a "solution frame" is illustrated by the oil spill in the Gulf of Mexico in 2010 when the "New York Times" reported that "scientists at BP's command center in Houston had drafted plans to work on and around an underwater blowout preventer, a massive safety device that is designed to seal an oil well in an emergency but failed to do so after the explosion at the rig" (Fountain \& Wald, New York Times, May 13, 2010, p. 1). In this case the solution is presented as a "blowout preventer." Therefore a solution frame is one in which a solution, answer, fix or effort is presented in the news story as addressing the issue of concern. I will measure a solution frame by examining news articles for specific solutions, answers, fixes or efforts to address the specific issue of chemical weapons in Hermiston, OR. For example, instructions to the coders will be as follows: 
After reading the entire new story, if a problem is identified please check a box for that article, then write down what the problem is. Indicate the number of times a solution is offered — either by the reporter or by a source — to the identified problem. Code and describe which party provided the solution(s). Examine the articles for thematic frames or episodic frames. DO NOT count the same solution more than once.

Community Pluralism: To measure community pluralism, I will use 2000 Census data to quantify various community characteristics. Recall the literature review showed that indicators of pluralism may include the population of the city, education levels of the residents, income and employment of residents, types of businesses, the number or variations of religious denominations, percentage of minority children in school, ratio of Black-White home ownership, and other ethnic based measures (Jeffres, Cutietta, Sekerka, \& Jae-Won, 2002). For the current study measures of pluralism include: population, educational attainment level, income, poverty levels, foreign birth by region, occupation, industry, and race or ethnicity. Based on the information obtained from Census data, Portland is considered the heterogeneous community and Hermiston the homogenous community.

Recall that the Census of 2000 showed that Portland's population was larger than Hermiston's ( $\mathrm{n}=529121 ; \mathrm{n}=13154)$. The distribution of race in Portland was: White 81.3 percent ( $\mathrm{n}=430350)$, Black or African American 7.9 percent $(\mathrm{n}=41589)$, American Indian and Alaska Native 2.3 percent $(\mathrm{n}=12125)$, Asian 7.5 percent $(\mathrm{n}=39485)$, Native Hawaiian and 'Other Pacific Islander' 0.7 percent $(\mathrm{n}=3658)$, Hispanic or Latino 6.8 percent 
$(\mathrm{n}=36058)$, and 'Some other race' $4.9(\mathrm{n}=25836)$. The distribution of race in Hermiston was: White 81.2 percent $(\mathrm{n}=10683)$, Black or African American 1.5 percent $(\mathrm{n}=192)$, American Indian and Alaska Native 1.6 percent $(\mathrm{n}=212)$, Asian 2.0 percent $(\mathrm{n}=265)$ Native Hawaiian and 'Other Pacific Islander' 0.1 percent ( $\mathrm{n}=18)$, Hispanic or Latino 24.1 percent ( $\mathrm{n}=3168)$, and 'Some other race' $16.4(\mathrm{n}=2162)$. So when the two cites are compared based on race both have a large white population. However, Portland's other races are more equally distributed than Hermiston's. Recall the literature concerning pluralism proposes that, "more differentiated communities would have more diverse sources of organized social power. Communities with greater degrees of differentiation would have a wider range of groups and institutions involved in community decisionmaking process (Hindman, Littlefield, Preston, \& Neumann, 1999, p. 250)”.

For example African, Asian, Hispanic or Latino races in Portland are all around 6 percent of the population. Compared to Hermiston having a relatively large Hispanic or Latino population, while the African race constitutes less than one percent and Asian 1.6 percent. Hermiston's second most populous race is Hispanic or Latino, and Portland's second most populous race is also Hispanic or Latino. The difference is that Hermiston's Hispanic or Latino population is nearly a quarter of the total population, whereas Portland's Latino or Hispanic population is less than a tenth of the total population. Hermiston's relatively large percent of the Hispanic or Latino race may be due to Hermiston's agricultural business's utilization of inexpensive labor. Two other measures of pluralism selected are educational attainment and per capita income. 
Recall that, if a community has a high level of structural pluralism many different groups potentially have a voice in community decision-making, whereas a community with low structural pluralism may have a few dominant groups that push the status quo on other groups. Hermiston is much more of an agricultural area than Portland. Of the total industry in the city of Hermiston, 6 percent is agriculture, while only 0.4 percent of Portland's industry is constituted by agriculture (Census, 2000). The greater emphasis on agricultural business in the community of Hermiston, when compared to Portland, may draw populations commonly employed in the field work of large scale farming, such as the Hispanic or Latino races. This demand for an inexpensive labor source, and the demand for work, appears to be reflected in which groups constitute relatively large percentages of Hermiston's population. The U.S. Census also reported that of those people that are foreign born in Hermiston, 82.8 percent are from Latin America, compared to Portland at 25.5 percent (See Table 1).

For example, Hermiston has a numerically dominant White population, the next largest percentage of the population is the Hispanic and Latino population. With the large amount of agriculture operations in the area, there is also a large migrant farm worker population which is often comprised of many Hispanic and Latino members. This may lead to a dualistic relationship between the two racial populations, especially considering that most of the agricultural business owners are White males. Even though Portland has a large and equally high percentage of Whites, there are other less dominant population groups that are more equally distributed, potentially representing more than two groups having some degree of power and voice in the community (See figure 4). For example, in 
Portland the African American population (6.6\%) and the Asian population (6.3\%) are as large as the Hispanic/ Latino population. In comparison to Hermiston, the African American population (0.9\%) and Asian population (1.6\%) are smaller than the Hispanic/ Latino population (24.1\%).

Of Portland's total population 85.7 percent have a diploma or greater and 32.6 percent have a bachelors degree or better, while of Hermiston's total population 74.5 percent have diploma or better and 14.5 percent have a bachelors degree or better. In other words, a greater percentage of people in Portland graduated from high school and college than those in Hermiston. The per capita income of Portland was $\$ 22,643$, and Hermiston's was $\$ 17,075$, this a 25 percent difference. In other words, the person in Portland would get paid a salary for twelve months out of a year of work, while the Hermiston resident would get paid for only nine months out of the same year of work. Portland State University economics professor, David Ervin, concluded this is a substantive difference in income (personal communication, May 22, 2011).

Portland had a greater percentage of its population in management, professional, and related occupations (37.2\%) compared to Hermiston (23.4\%). While Portland had a lower percentage $(0.2 \%)$ of population employed in farming, fishing, and forestry compared to Hermiston (3.3\%). Of the families in Hermiston a greater percentage fall below the poverty line (11.9\%), compared to Portland families below the poverty line (8.5\%). Other occupations and industries compared are shown in Table 2. 


\begin{tabular}{|c|c|c|}
\hline & Portland & Hermiston \\
\hline population & 529,121 & 13,154 \\
\hline per capita income & $\$ 22,643$ & $\$ 17,075$ \\
\hline RACE & percent & percent \\
\hline White & 81.3 & 81.2 \\
\hline African American or Black & 7.9 & 1.5 \\
\hline American Indian and Alaska Native & 2.3 & 1.6 \\
\hline Asian & 7.5 & 2.0 \\
\hline Native Hawaiian and 'Other Pacific Islander' & 0.7 & 0.1 \\
\hline Hispanic or latino & 6.8 & 24.1 \\
\hline 'Some other race' & 4.9 & 16.4 \\
\hline \multicolumn{3}{|l|}{ FOREIGN BIRTHS BY REGION } \\
\hline Europe & 25.5 & 2.6 \\
\hline Asian & 38.1 & 12.5 \\
\hline Africa & 3.5 & 0 \\
\hline Oceania & 2.6 & 0.6 \\
\hline Latin America & 25.5 & 82.8 \\
\hline North America & 4.8 & 1.6 \\
\hline \multicolumn{3}{|l|}{ EDUCATIONAL ATTAINMENT } \\
\hline percent high school graduate or higher & 85.7 & 74.5 \\
\hline percent bachelor's degree or higher & 32.6 & 14.5 \\
\hline enrolled in college & 32.1 & 14.9 \\
\hline \multicolumn{3}{|l|}{ POVERTY STATUS IN 1999} \\
\hline Families & 8.5 & 11.9 \\
\hline with related children under 18 years & 13.2 & 17.5 \\
\hline with related children under 5 years & 16.8 & 22.8 \\
\hline
\end{tabular}

Table 1. Demographic characteristics of two cities selected. Source: U.S. Census Bureau, Census 2000. 


\section{OCCUPATION}

Management, professional, related occupations

Service occupations

Sales and office occupations

Farming, fishing, and forestry

Construction, extraction, and maintenance

Production, transportation, and material moving

\section{INDUSTRY}

Agriculture, forestry, fishing and hunting

Construction

Manufacturing

wholesale trade

Retail trade

Transportation, warehousing, and utilities

Information

Finance, insurance, real estate, and rental and leasing

Professional, scientific, management, administrative, and waste management services

Educational, health, and social services

Arts, entertainment, recreation, accommodation and food services

Other services (except public administration)

Public administration

\section{Portland Hermiston}

\begin{tabular}{|r|r|}
37.2 & 23.4 \\
\hline 15 & 17.3 \\
\hline 26.5 & 24.5 \\
\hline 0.2 & 3.3 \\
\hline 7 & 9.8 \\
\hline 14 & 21.7
\end{tabular}

$0.4 \quad 6$

$5.4 \quad 5.7$

$12.5 \quad 10.9$

$\begin{array}{ll}4.6 & 3.7\end{array}$

$11.5 \quad 17.3$

$5.5 \quad 9.3$

$3.2 \quad 1.3$

$6.9 \quad 4.4$

$12 \quad 4.6$

$19.7 \quad 14.8$

$9.4 \quad 9.3$

$5.5 \quad 5.6$

$3.4 \quad 7.1$

Table 2. Demographic characteristics of two cities selected (continued). Source: U.S. Census Bureau, 


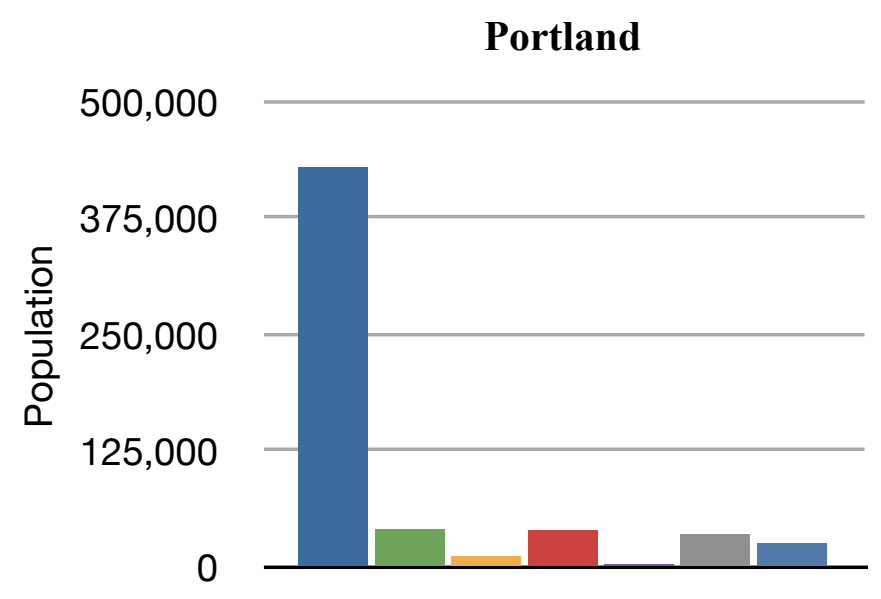

\section{Hermiston}

\section{5,000}

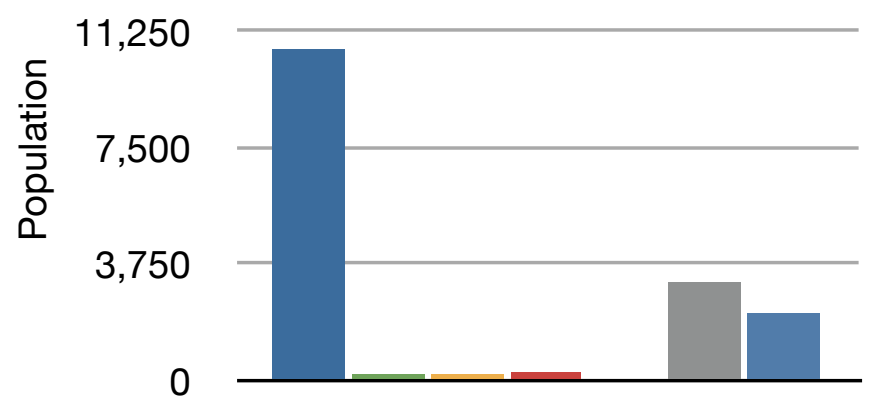

White

Black or African American

American Indian and Alaska Native

Asian

Native Hawaiian and other Pacific Islander

Hispanic or Latino (of any race)

Some other Race

Figure 4. Race Distribution of Two Communities. Order of races proceeds left to right on the $\mathrm{X}$ axis

beginning with White. The number for each race may add to more than total population because individuals may report more than one race. Source U.S. Census Bureau, Census 2000. 


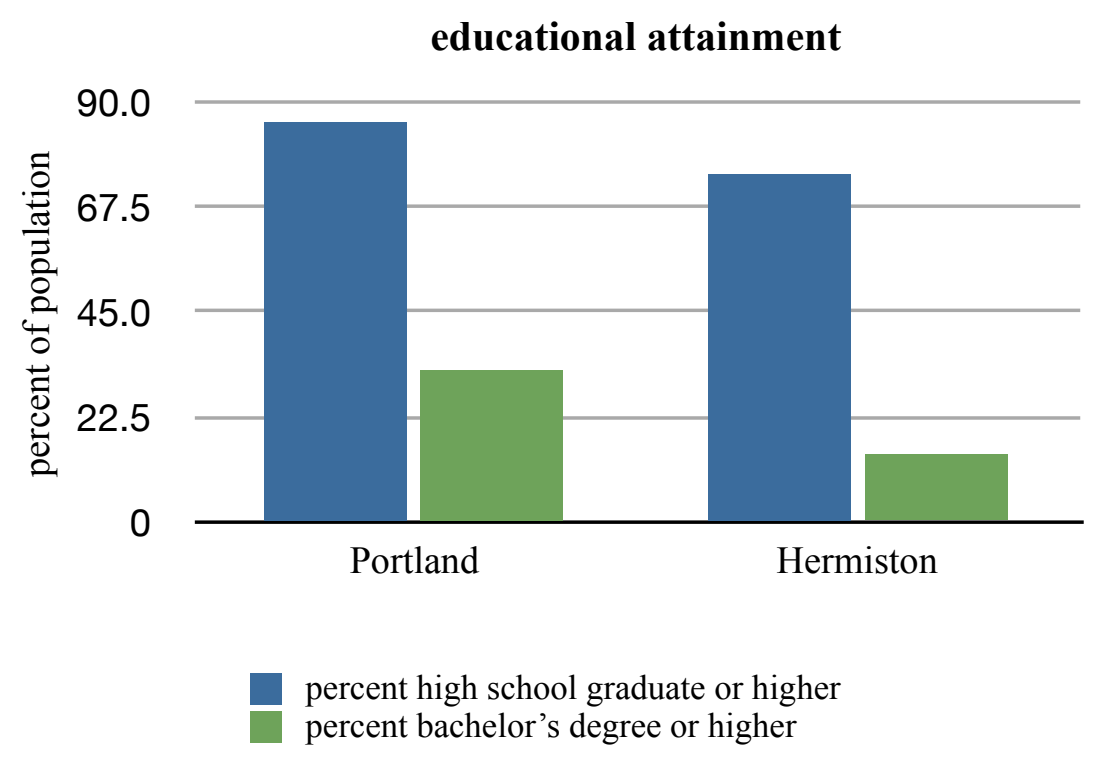

Figure 5. Educational Attainment of Two Communities.

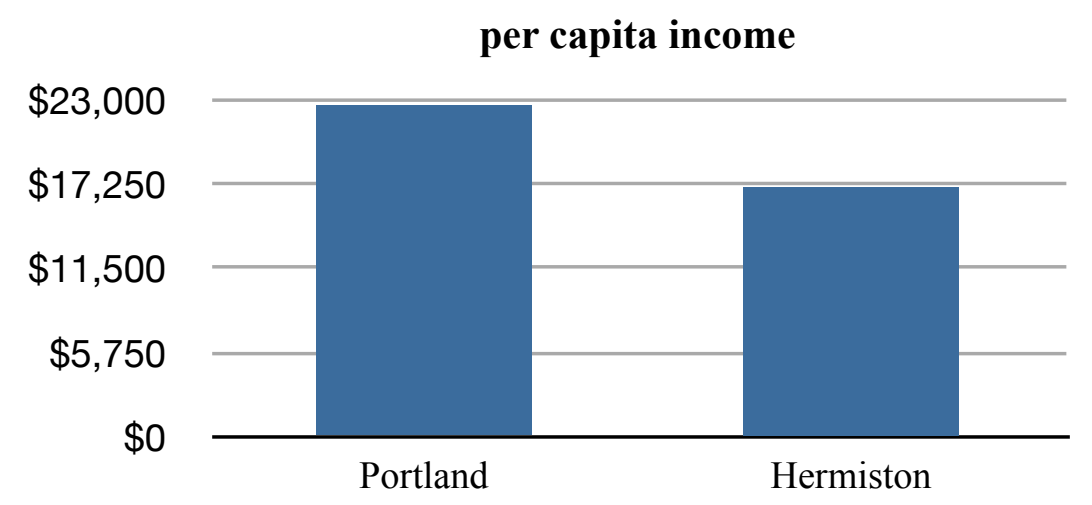

Figure 6. Per capita income of two Communities.

Pluralistic Frame: The literature review showed that structural pluralism is related to the diversity of a community (Tichenor, Donahue, \& Olien, 1980). In the most basic sense if a community has a high level of structural pluralism, many different groups will have a voice in the community. For the current study, when a frame contains different voices or positions I will identify it as a pluralistic frame. My operationalization of 
pluralistic frame is as follows: a news story concerning the Umatilla chemical weapons depot that contains more than one solution or fix to the problem of chemical weapons disposal. To that end, coders will be instructed to examine news stories for solutions and when more than one solution is present the coder will mark this on the coding checklist (Appendix-B).

Episodic Frame: Recall that the literature demonstrates that news frames that are episodic contain very little context surrounding the story. For example, episodic frames typically will not provide the history or events that may have led to a problem, or the long-term implications of a solution provided in the news story. Episodic frames are micro analytical in scope. My operationalization of episodic frame is as follows: a frame concerning the Umatilla chemical weapons depot and/or incinerator that contains no historical background or long-term future implications of incineration, for example. To that end, coders will be instructed to examine news stories for the chronologic scope of the story. If it is a snapshot with little context the coders will count it as an episodic frame.

Thematic Frame: The literature notes that thematic frames show trends and historical conditions that may have contributed to a problem, as well as future implications. Thematic frames are macro analytical in scope. My operationalization of thematic frame is as follows: a frame concerning the Umatilla chemical weapons depot and/or incinerator that contains historical background or long-term future implications. To that end, coders will be instructed to examine news stories for the chronologic scope of the story. If it is a long term analysis of the problem with historical context the coders 
will count it as an episodic frame. The coders will be provided example of both types of frames. 


\section{Chapter 5. Purpose of Study and Research Design}

In this study I explore the use of "solution frames," and what I have termed "pluralistic frames," in news coverage of the chemical weapons stockpile in Eastern Oregon. I compared frame use across the two community newspapers in Portland and Hermiston. I examine frames from the construction or creation aspect within the news reporter's domain. Recall that Entman asserts that the field of framing suffers from muddled definitions, so I also hope this study will contribute to the body of knowledge and help to clarify concepts concerned with framing paradigms and in particular the concept of the solution frame (1993).

\section{RESEARCH DESIGN}

In order to examine frames, I selected two newspapers: one from a large heterogeneous community newspaper and the other a small homogenous community newspaper. The two communities and corresponding newspapers selected are Portland, Oregon (The Oregonian) and Hermiston, Oregon (The Hermiston Herald). Portland was selected as the largest city with a population of 529,121 (US Census, 2000). Portland was founded in 1851 . The city was named after a coin toss between two land owners in 1845 (Portland City Auditor, 2010). The daily newspaper, The Oregonian, is the largest newspaper with a circulation of well over half a million each year during the years from 1994-1998. The Oregonian, the oldest newspaper in continuous production west of Salt Lake City, Utah, was founded by Thomas J. Dryer on December 4, 1850 (Stein, 2008). 
Currently, The Oregonian is owned by Advance Publications, a large media conglomerate that owns numerous newspapers, magazines, cable channels, and internet news outlets (Advance.net, 2011). Portland is one hundred and eighty three miles from Hermiston. The local newspaper, The Hermiston Herald, was founded in 1906 by Horace Newport and William Skinner (The Hermiston Herald, 2010). The newspaper has since had three owners. Jerry Reed purchased the paper in 1974, Western Communication Inc. of Bend, Oregon, purchased the papers from Reed, and in 2008 the paper was purchased by East Oregonian Publishing Co., of Salem, Oregon. The circulation of The Hermiston Herald is less than 10,000 papers a year (Hermiston Herald, 2010). The town of Hermiston was incorporated on July 10, 1907, and the town's name was inspired by Robert Louis Stevenson's novel, “The Weir of Hermiston” (Tucker, 2002). The population of Hermiston is 13,154 (US Census, 2000). Hermiston is also the closest community to the chemical weapons incinerator.

The following hypotheses and research questions compare coverage of the two community newspapers. In order to compare how news coverage differs across communities, I predict that fewer pluralistic frames will occur in coverage in the Hermiston newspaper than in the Portland newspaper. I wish to see if this is true in a comparison of Portland and Hermiston's newspaper coverage. 


\section{Chapter 6. Hypotheses and Research Questions}

Based on literature asserting that the characteristics, such as structural pluralism, of a community may influence the type of newspapers coverage, I predict:

Hypothesis 1. Solution frames (single solution) will be more likely to appear in the newspaper articles from Hermiston than the Portland-based newspaper at a statistical significance.

Based on the literature which shows that a local newspaper will embody the pluralism of the surrounding community, I predict:

Hypothesis 2. Pluralistic frames will be more likely to appear in the newspaper from Portland, than the Hermiston-based newspaper at a statistical significance.

Based on the literature concerning activist groups involvement in media campaigns, I propose:

Hypothesis 3 . When more than one solution is provided in the news story the additional solutions will be challenger group positions or alternative viewpoints instead of dominant or status quo frames at a statistical significance.

\section{Research Questions}

In addition, I will explore to what degree solution frames-both those containing a single solution and those with two or more-include episodic scope and thematic scope frames. The following research questions arose from the literature showing that episodic frames are prevalent in coverage of community issues, and that status quo positions 
dominate when the media function to reassure the public concern (Iyengar, 1999;

Bennett, 1988).

Research Question 1: To what extent do solution frames include episodic or thematic content?

Research Question 2: To what extent do pluralistic frames include episodic or thematic content?

\section{Newspapers}

Recall that two newspapers were selected because of their location in communities with different levels of pluralism (The Oregonian and The Hermiston Herald). Two different techniques were employed in order to derive a sample of coverage of the chemical weapons depot and/or incinerator for case study. For The Oregonian a search of the LexisNexis database was conducted using the keywords: "incineration" and “chemical weapons” from January 1, 1994 to December 31, 1998. LexisNexis Academic Universe is an online database containing full text copies of, among other documents, regional and national newspapers. These two terms were selected because they are critical components of the solution frame under investigation, and yielded the highest number of pertinent articles when compared to other search terms (e.g. "nerve agent"). During preliminary research it appeared chemical weapons are the most common problem detailed in both newspapers' articles, and the dominant solution to the problem of chemical weapons is the disposal technology of incineration.

The LexisNexis database was not available for the news stories from The Hermiston Herald. I used a technique to mirror The Oregonian search. I physically 
searched the hard-bound archives of The Hermiston Herald, from January 1, 1994, to December 31, 1998, selecting all articles containing the words "incineration" or "chemical weapons" in the title and/or body of the article. The Oregonian is a daily paper, The Hermiston Herald is published twice weekly on Wednesdays and Saturdays. 


\section{Chapter 7. Methods}

The Hermiston Herald lacks an electronic database of newspaper archives. However, analog archives are available to public examination. I created a list of the articles from The Hermiston Herald that contained the same search terms used for The Oregonian electronic: "incineration" and "chemical weapons." Recall that these two terms were selected because they are critical components of the solution frame under investigation, and yielded the highest number of pertinent articles when compared to other search terms (e.g. "nerve agent"). Duplicates and articles deemed not relevant were removed. For example, several articles that concerned the Toole, Utah, chemical weapons incinerator were present in the sample. If these articles did not mention the city of Hermiston or the Umatilla chemical weapons incinerator they were eliminated.

Some articles were missing due to circumstances beyond my control. An employee of The Hermiston Herald volunteered to help photocopy articles based on the list I created. After reviewing the list and articles, I discovered that eleven articles were missing, and I determined this would not adversely affect the study. I created a file with all of the articles from The Oregonian (150) and The Hermiston Herald (178), (total n=328). For the study, I decided to use a sample of the entire set and selected these articles at random. In order to capture a random sample, I used a 95 percent confidence level and confidence interval of 5, resulting in a total of 178 articles for a reliable sample. To increase validity and minimize potential bias, a random number generator was used to select the order of the articles. The articles from The Oregonian totaled 81, while The Hermiston Herald sample had 97 articles. 
The sample of articles $(\mathrm{n}=178)$ was coded by two Portland State University students. Two coders were selected to increase the rigor of coding. The task of developing and applying codes is complex. Two meetings were arranged prior to coding. During these meetings coders were informed of the procedure of coding. Fifty percent of each newspaper sample was combined and placed in three-ring binders. An intercoder reliability test was performed with 11.7 percent of the articles selected randomly. Results of the intercoder reliability test, newspaper article selection, and statistical analysis are included in the Results Chapter. 


\section{Chapter 8. Results}

\section{Content Analysis}

Recall that reliability is a critical component in any study with data collection and coding. For this study, in order to test intercoder reliability, 21 articles (11\%) were coded by both coders. The sample of 10 percent was selected randomly, and is recommended by “The Content Analysis Guidebook" (Nuendorf, 2002). Intercoder reliability can be measured utilizing a variety of tools. In this case, because coders were instructed to determine the presence or absence of frames, only two choices were available. Because choices were dichotomous, I utilized simple agreement to check intercoder reliability as follows: The intercoder agreement for variable one (presence of a problem in an article) was 95.2 percent. Agreement for variable two (presence of a solution in an article) was also 95.2 percent. Agreement for variable three (presence of more than one solution in an article) was 81 percent. Agreement for variable four (contains episodic framing) was 76.2 percent. Agreement for variable five (contains thematic framing) was also 76.2 percent. All of the above percentages are within acceptable levels. The mean intercoder agreement was 84.8 percent.

Before counting solutions, I had coders note whether each story contained "a problem." This served as a way to filter stories that could have solution frames. Recall that Hypothesis 1 proposed that when comparing news coverage across communities, solution frames will be more likely to appear in the newspaper from Hermiston than the Portland-based newspaper. I found that 80 percent $(n=61)$ of the stories in The Hermiston Herald that had a problem, contained a solution frame. Of the stories in The Oregonian 
with a problem, 77 percent $(n=53)$ contained at least one solution frame. Since the total for The Oregonian and The Hermiston Herald were not identical, I tested the results using chi-square statistics. Hypothesis 1 was not supported, $\left(X^{2}=.001 ; p=. .97\right)$. In other words, the presence of solution frames did not vary at a statistically significant level between newspapers.

Table 3. Results of coding for hypotheses $1 \& 2$.

\begin{tabular}{|c|c|c|c|c|c|c|}
\hline $\begin{array}{l}\text { Hypothesis } 1 \\
\text { Hypothesis } 2\end{array}$ & & $\begin{array}{l}\text { has } \\
\text { problem }\end{array}$ & $\begin{array}{c}\text { has } \\
\text { solution }\end{array}$ & $\begin{array}{l}1 \text { solution } \\
\text { only }\end{array}$ & $\begin{array}{l}2 \text { solutions } \\
\text { (pluralistic ) }\end{array}$ & $\begin{array}{l}3 \text { solutions } \\
\text { (pluralistic) }\end{array}$ \\
\hline $\begin{array}{l}\text { Hermiston } \\
\text { Herald }\end{array}$ & subtotals- & 61 & 49 (80\%) & $21(34 \%)$ & 24 (39\%) & $8(13 \%)$ \\
\hline \multirow[t]{2}{*}{ Oregonian } & subtotals- & 53 & 41 (77\%) & $20(38 \%)$ & 21 (40\%) & $2(4 \%)$ \\
\hline & totals & 114 & $90(79 \%)$ & $41(36 \%)$ & 45 (39\%) & 10 (9\%) \\
\hline
\end{tabular}

Recall Hypothesis 2 proposed that when comparing news coverage across communities, pluralistic frames will be more likely to appear in the newspaper from Portland than the Hermiston-based newspaper. Of The Hermiston Herald stories with a problem identified, 52 percent $(n=32)$ contained a pluralistic frame, while only 43 percent $(\mathrm{n}=23)$ of the stories with a problem identified in The Oregonian sample contained pluralistic frames. The differences were not statistically significant and therefore Hypothesis 2 was unsupported $\left(\mathrm{X}^{2}=2.6 ; \mathrm{p}=.10\right)$. In other words, the presence of pluralistic frames did not vary at a statistically significant level between newspapers.

Recall Hypothesis 3 proposed that when more than one solution is provided in the news story, the additional solutions will be challenger frames or alternative viewpoints instead of dominant or status quo frames. In this case the two newspapers are not being 
compared, but all stories containing more than one solution are being examined for the framing of the additional solutions. In other words, my unit of analysis is not the newspaper articles but the solutions within the article. To address Hypothesis 3, I examined the descriptive coding sheets. I found that of all the pluralistic frames 82 percent $(\mathrm{n}=55)$ are positions opposing incineration, and 18 percent were dominant frames supporting incineration. Hypothesis 3 was supported $\left(X^{2}=55 ; \mathrm{p}=.00\right)$. In other words, the type of solution did vary at a statistically significant level within pluralistic frames.

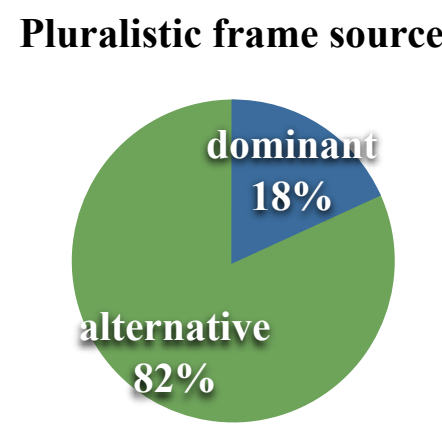

Figure 7. Sources identified in pluralistic frames.

An example of an alternative frame, provided by activist Karyn Jones, is as follows: "We are completely opposed to incineration. We are actually opposed to any open loop method of destruction" (Early, 1994, p. A3). An example of the dominant frame is a quote provided in the same article by Hermiston Mayor Frank Harkenrider: We have been studying this thing for nine years, the bottom line is the longer you wait the riskier it gets. I think they've proven (the) technology beyond a reasonable doubt that they can dispose of the chemical weapons out there with incineration. (Early, C., 1994, p. 
For the research question concerning the extent to which articles with solution frames — including single and pluralistic — include episodic and thematic content, the unit of analysis is again the newspaper story. Articles with one solution contained episodic frames in 80 percent $(n=33)$ of the articles, and thematic frames were present 20 percent $(n=8)$ of the articles. In the articles with more than one solution (pluralistic frames), episodic framing was present 67 percent of the time $(n=30)$, while thematic framing appeared in 33 percent $(n=15)$ of the articles with multiple solutions. Solution frames were dominated by episodic frames $\left(\mathrm{X}^{2}=29.3 ; \mathrm{p}=.00\right)$. The results showed that episodic frames are statistically less likely to appear than thematic frames in stories with pluralistic frames. The statistical analysis of pluralistic frames for episodic and thematic framing again showed a prevalence of episodic framing $\left(\mathrm{X}^{2}=7.2\right.$ and $\left.\mathrm{p}=.007\right)$. The potential implications of the results are covered in the discussion section.

Table 4. Results of coding for research questions.

\begin{tabular}{|c|c|c|c|c|c|}
\hline \multirow[t]{3}{*}{ RQ 1} & $\begin{array}{l}\text { solution frame } \\
n=41\end{array}$ & episodic & & thematic & $X^{2}=29.3 ; p=.00$ \\
\hline & $\mathrm{HH}(\mathrm{n}=21)$ & 17 & $41 \%$ & 4 & $10 \%$ \\
\hline & Oregonian $(n=20)$ & 16 & $39 \%$ & 4 & $10 \%$ \\
\hline total & & 33 & $80 \%$ & 8 & $20 \%$ \\
\hline \multirow[t]{3}{*}{ RQ 2} & $\begin{array}{l}\text { plural frame } \\
\text { count } n=45\end{array}$ & episodic & & thematic & $\mathrm{X}^{2}=7.2 ; \mathrm{p}=.007$ \\
\hline & $\mathrm{HH}(\mathrm{n}=24)$ & 19 & $42 \%$ & 5 & $11 \%$ \\
\hline & Oregonian $(n=21)$ & 11 & $24 \%$ & 10 & $22 \%$ \\
\hline total & & 30 & $67 \%$ & 15 & $33 \%$ \\
\hline
\end{tabular}




\section{Chapter 9. Discussion}

Why study newspaper coverage? One good reason is to see if the free press is a myth, as Bennett proposes. If we realize that there is no longer a free press and the press is no longer serving the watchdog function of keeping those in power honest and ethical, what should be done? It has been suggested the best action to protect the democratic discussion within society is for regular citizens to become journalist using technological advances such as social media websites (e.g. Facebook). A study by Elizabeth Vail showed:

hyperlocal citizen journalists, some trained in journalism and some not, continue to take a serious watchdog role in their local geographic areas. They continue to offer information, although not necessarily "objective" information, to the public for its use in the democratic process. The results are encouraging as journalism is evolving but may retain some of the necessary elements connected to the functioning of democracy. (2009, p.4)

We could protest at Federal Communication Commission hearings or in front of the local newspaper office or we could write letters to the newspaper about how they cover issues. I think another, potentially more effective route is to continue to sound the alarm. By "sound the alarm" I am referring to exposing the shortcomings of our media through rigorous research.

For example, the concept framing is increasingly used by media critics to show how stories are being constructed. I would be ecstatic to hear a friend of mine who does not study media, say something like, "Oh, they are using a solution frame, I wonder what solution is missing," or, "I am glad they are using a pluralistic frame." As unlikely as this 
may be, the point is until the audience is able to realize what is lacking, and preventing insight, media companies are going to continue to give us what the Romans termed, "bread and circus," essentially stories that contain no threat to the status quo.

Another reason is to educate myself about the information being provided by the press. I certainly think that my thesis journey has illuminated my understanding of complexities of communication, improved my skills as a researcher, provided a glimmer of hope on the cloudy horizon that is the state of mass media, and reinforced some of my concerns about the poor quality of news coverage. I have gained a greater understanding of framing. For example, I have been confused about whether a frame can be contained within a frame. Now I believe that this layering is occurring. I now see framing possessing a structure similar to systems analysis, whereby a system is defined by where the researcher places the boundaries of the system. For example, if your system boundary is a solution frame, that system may also contain an episodic frame. However, I do not believe that an episodic frame can contain a solution frame. In other words, I believe that some frames supersede other frames.

Another area of communication knowledge that has been enhanced by this study is my understanding of the balancing norm. According to Bennett, a balancing norm may be present when, "authoritative voices of officials who normalize interpretations of the otherwise threatening and confusing event in the news" (1988, p. 24). However, in the case of the Umatilla incinerator state government authoritative voices were often not normalizing the threat of chemical weapons and/or incineration. This was unexpected, in that many of the additional solutions provided were supplied by authoritative voices. For 
example, Governor John Kitzhaber calling for delay in issuing permits for safety reasons. Authoritative voices supporting alternatives occurred frequently with many alternative positions provided by sources that may be considered authoritative or official, and these sources were attempting to expose the risk of incineration instead of normalizing the problem and supporting the Army Corps position that incineration is the only solution.

For example, the Governor not only tried to delay permits for incineration, he also formed the the Citizens Advisory Committee on Demilitarization (CACD), and other officials supported investigation of, or use of, alternatives to incineration. Other authoritative voices not normalizing the situation included congressman Peter Defazio, U.S. Representative Bob Smith, U.S Senator Gordon Smith, and the Oregon Department of Environmental Quality. I have come to the conclusion that it may not have mattered who (short of the President) called for the use or even investigation into alternatives to incineration. The Army and Raytheon Corporation had previous business relationships and Raytheon had the "lowest" bid. Although the Army attended the public meetings, listened to concerns, supplied expert testimony supporting incineration, and "explored" alternatives technologies, during the same period of time construction of the incinerator carried on without delay.

Although I was not expecting the local newspaper to act pluralistically, I see the results as heartening. In this case The Hermiston Herald is acting like a newspaper from a larger and more pluralistic community, providing a voice for challenger groups. This begs the question of why is The Hermiston Herald providing more information concerning the solutions to the problem of chemical weapons? One reason may be the community's 
proximity to the risk. The community served by The Hermiston Herald is less than twenty miles from the incinerator, while the city of publication for The Oregonian is nearly two hundred miles from the incinerator. The reporters of The Hermiston Herald may seek out more sources and solutions due to the belief that the local residents are in the greatest risk of harm from the chemical weapons. The reporter from The Oregonian may not be as vigilant due to the problem of chemical weapons being a greater distance from the majority of readers.

Another potential reason for The Hermiston Herald's reporting is the access of reporters to challenger groups and local activists. During the reading of the descriptive coding sheets, various activist and challenger groups were identified. For example: (1) The Chemical Weapons Working Group (CWWG), (2) The Group Against Smog and Pollution (GASP), (3) Oregon Physicians for Social Responsibility (OPSR), (4) The Citizens Advisory Committee on Demilitarization (CACD). However, none of these groups is based in Hermiston. The Chemical Weapons Working Group (CWWG) is based in Kentucky, the Group Against Smog and Pollution (GASP) is based in Pennsylvania. However, the majority of public meetings were held in Hermiston and the representatives of these groups attended the meetings often. Therefore, the greater access to challenger groups may have been available to the reporter of The Hermiston Herald, while The Oregonian may not have been willing to send a reporter to every public meeting in Hermiston.

The results of my research question concerning the use of episodic and thematic themes in both solution frames and pluralistic frames revealed that the use of episodic 
framing dominates both categories, as well as both newspapers. Episodic framing is short or a snapshot, while thematic frames contain greater context concerning the problem. It is clear from the results that episodic framing dominates stories concerning the Umatilla incinerator. I believe that reporters are capable of providing more thematic framing, and I also believe that doing so provides concerned citizens with more access to comprehensive information required to participate effectively in the public debate process.

I believe, when there is an issue of potential danger, there is great value in pluralistic frames with a thematic scope. The value lies in the comprehensive information provided in stories that embody these characteristics; information that allows citizens in a democracy to make truly informed decisions concerning issues that may have a dramatic effect on their well-being. The question remains of how to encourage reporters to implement frames with more context and challenger sources. It would be futile for reporters to make this change due to the risk to their own careers. For example, If a small local newspaper started to report in a manner that promoted dialogue within a community the reporter may receive "flak" from the elites and/or supporters of the dominant position. David Cromell described an example of flak as:

It (flak) may take the form of letters, telegrams, phone calls, petitions, law-suits, speeches and Bills before Congress, and other modes of complaint, threat and punitive action'. Business organizations regularly come together to form flak machines. Perhaps one of the most well-known of these is the US-based Global Climate Coalition (GCC) - comprising fossil fuel and automobile companies such as Exxon, Texaco and Ford. The GCC was started up by Burson-Marsteller, one of the world's largest public relations companies, to 
rubbish the credibility of climate scientists and (write) 'scare stories' about global warming. (2002, p. 37)

Therefore, for reporters to be more thorough would require regulation or topdown media reform. As McQuail proposes, "the only indications of steps that can protect democratic institutions seem to lie in the direction of some forms of public regulation designed to sustain a reasonable degree of access, diversity, quantity, and quality of information and sufficient impartiality" ( 2003, p. 203). However, currently increased media regulation appears to be an idealistic request. Therefore, tactics using bottom-up reform may be required. I believe that a combination of accessible publications grounded in media research and theory, an increase in alternative media source consumption (e.g., independent online media, international media outlets such as the LinkTV, or individual independent guerrilla journalists operating via social media websites), and public mobilization are the tactics that will act as water on the stone that is corporate media conglomeration.

If we cannot reform the media then we must become the media, because, "Every story in the paper could be recast with a more honest and human point of view, one not reflecting the interests of the powerful. But expecting them to do that on their own initiative is like expecting General Motors to give away its profits to poor people in the slums" (Chomsky, 2002, p. 46). The study has served to further explicate the concept of the solution frame, introduce the pluralistic frame, reinforce the research showing that mass media is dominated by short-sighted status quo positions, and in doing so hopefully 
supply heuristic value to the field of communication and the multiparadigmatic concept of framing. 


\section{Chapter 10. Limitations and Future Studies}

One limitation of a case study is generalizabilty. The results of this study are specific to the case at hand, and cannot be generalized to other environmentally risky scenarios. Another potential limitation of the study is the eleven articles missing from the The Hermiston Herald sample. Of the total articles for the study, prior to randomization and sampling to obtain a 95 percent confidence level and confidence interval of 5 $(n=328)$, the eleven articles constitute only .03 percent. The missing articles did not fall in a particular year or day of the week. It would potentially be beneficial to include additional communities and newspapers in a future study.

Epilogue

Portland and Hermiston have continued to grow in population. Portland's population has increased from 529,121 in 2000 to 583,776 in 2010 (9\%), and Hermiston's population has risen from 13,154 in 2000 to 16,745 in 2010 (27\%). Hermiston has seen a relatively dramatic increase in population, not only in relation to Portland, but compared to other cities in Eastern Oregon. For example, Pendleton, OR, was the largest city in Eastern Oregon for a century. However, Hermiston has now passed up Pendleton for title of largest city in Eastern Oregon, as the Mayor turned council person Frank Harkenrider told The Oregonian, "It's taken us a 103 years!" (Cockle, R., 2011 April 21). Also, Hermiston's Hispanic and Latino population has grown from a little over a quarter of the population in 2000 to a third in 2010 (“Hermiston's recipe...”, 2011, pp.1-2). According to the 2010 U.S. Census, per capita income in the two cites changed from 2000 to 2010. 
Portland's per capita income rose from $\$ 22,643$ to $\$ 29,137$, while Hermiston's per capita income only rose from 17,075 to $\$ 18,745$. It appears that Hermiston has grown enough to eclipse the local rival city of Pendleton in size and the standard of living has risen for some Hermiston's population. As of May, 1, 2011 the Army has incinerated 75 percent of the original 7.4 million pound stockpile. Whether or not the concerns of the local challenge groups voiced in the Hermiston Herald and The Oregonian articles (such as airborne toxins from the incineration of the chemical weapons) are well founded, remains to be seen. 


\section{References}

2000 U.S. Census. Downloaded November, 3, 2010 at: http://censtats.census.gov/cgi-bin/ pct/pctProfile.pl

Advance.net (2011). About us. Advance Publications. Retrieved May 25, 2011; at: http:// www.advance.net/index.ssf?/advance_internet/about_advance_net.html

Bennett, L. W. (1988). News: the politics of illusion. NY: Longman Pub.

Bumb, R. P., Crumtnett, W. B. Cutie, S. S, Gledhill, I. R., Huinmel, R. H., Kagel, R. O., Lampatski, L. L., Luoma, E. V., Miller, D. L., Nestrick, T. J., Shadoff, L. A., Stehl, P. H., Woods, I. S. (1980). Trace chemistries of fire: A source of chlorinated dioxins. Science, 210 (4468). Obtained online at stable URL: http:/llinks.jstor.org/sici? sici $=0036-8075 \% 2819801024 \% 293 \% 3$ A210\%3A4468\%3C385\%3ATCOFAS \%3E2.0.CO\%3B2-W

Carragee, K. M., and Roefs, R. (2004). The neglect of power in recent framing research. Journal of Communication. International Communication Association (June). Chomsky, Noam. (2002). The common good: interviewed by David Barsamian. (Ed.) Arthur Naiman. Odonian Press, Tucson, AZ.

Cockle, R. (2011). Hermiston eclipses Pendlton as Eastern Oregon's biggest city. The Oregonian. Obtained online at: http://www.oregonlive.com/pacific-northwest-news/ index.ssf $/ 2011 / 04 /$ hermiston_eclipses_pendleton_as_eastern_oregons_no_1_city_by_population.html 
Coleman, C-L, and Corbitt, J. (2003). The social construction of mental health and depression: a work in progress. Equid Novi 24, (1): 99-114.

Creswell, J. W. (1998) Qualitative inquiry and research design: choosing among the five traditions. Sage Publication, Thousand Oaks, CA.

Demers, D. K. (1998). Structural pluralism, corporate newspaper structure, and news source perceptions: another test of the editorial vigor hypothesis. Journalism \& Mass Communication Quarterly 73, (3): 572-592.

Department of Defense. (2004). Medical Management of Nuclear Biological Chemical Warfare. http://www.nbc-med.org

D’Angelo, P. D. (2002). News framing as a multiparadigmatic research program: A response to Entman. Journal of Communication (December).

Entman, R. M. (1993). Framing: Toward a clarification of a fracture paradigm. Journal of Communication 43 (4) Autumn.

Fountain, H. and Wald, M. L. (2010, May 13). BP say leak may be closer to a solution. The New York Times, p. 1.

Freelon, G. D. (2010). ReCal: Intercoder reliability calculation as a web service. International Journal of Internet Science, 5(1) 20-23

Gamson, W. and Andre M. (1989). "Media Discourse and Public Opinion on Nuclear power: A Constructionist Approach." American Journal of Sociology 95: 1-37 Gramsci, A. (1971). Selections from the Prison Notebooks. London: Lawrence and Wishart. 
Habermas, J. (1962). The structural transformation of the public sphere: Inquiry into a Category of Bourgeois Society.

Herman, E. S. (1998). Privatizing public space. In D. K. Thussu (Ed.), Global media and local resistance (pp. 125-134). New York, NY: Oxford University Press.

Herman, E. S., Chomsky, N. (1988). Manufacturing consent: A propaganda model. Pantheon Books, NY.

Hertog, J. K., \& McLeod, D. M. (2003). A multiperspectival approach to framing analysis: A field guide. In S. D. Reese, O. H. Gandy, \& A. E. Grant (Eds.); Framing public life (pp. 139-162). Mahwah, NJ: Lawrence Erlbaum Associates.

Hindman, D. B., Littlefield R., Preston A., \& Neumann D. (1999). Structural pluralism, ethnic pluralism, and community newspapers. Journalism \& Mass Communication Quarterly 76(2), Summer.

Hofstede, G. (1980). Culture's consequences: international differences in work-related values. Beverly Hills, Sage.

Iyengar, S., (1991) Is Anyone Responsible?: How Television Frames Political Issues. University of Chicago Press.

Jeffres, Leo W., Cutietta, Connie, Sekerka, Leslie, and Lee, Jae-won. (2000).

Newspapers, pluralism, and diversity in an urban context. Mass Communication and Society. 3 (2/3, Spring/Summer), 157-184

Kurasaki, S. K. (2000). Intercoder reliability for validating conclusions drawn from openended interview data. Field Methods, 12(3), August 2000 179-194. Downloaded from fmx.sage.publishing at Portland State Univ on April 25, 2011. 
LexisNexis Academic Universe (2004). Keywords: "Umatilla", and "leak". http:// proxy.lib.pdx.edu:2056/universe/form/academic/s_guidednews.html? $\underline{\mathrm{m}=7 \mathrm{c} 1427 \mathrm{~b} 0 \mathrm{e} 44988 \mathrm{ed} 0941 \mathrm{c} 60 \mathrm{~cd} 457 \mathrm{~b} 4 \mathrm{fe} \& \mathrm{wchp}=\mathrm{dGLbVlb}-}$ zSkVA\& md5=245972d590714f4aacd411dc312e06ca

Lippmann, W. (1932). The World Outside and the Pictures in our Heads. Public Opinion. New Brunswick, N.J., Transaction Publishers. Downloaded 1 September 2004 from the American Studies Department, University of Virginia. http://xroads.virginia.edu/ 〜Hyper2/CDFinal/Lippmann/ch01.html Miller, M. (2002). What's Wrong With This PIcture? Obtained online April http:// www.thenation.com/special/bigten.html Morgan, L. (2004). Combining Qualitative and Quantitative Methods: making the Right Choices. Outline from upcoming publication by Sage Publishing p. 1-4 Nadakavukaren, A. (2000). Our global environment: A health perspective. Prospect Heights, Ill: Waveland Press, (pp. 196-197, 238-241, \& 657) Nelson, E. T., \& Willey, A. E. (2004). Issue Frames That Strike a Value Balance: A Political Psychology Perspective. In S. D., Reese, O. H. Gandy. Jr., \& A. E. Grant (Eds.), Framing Public Life: Perspectives on Media and Our Understanding of the Social World (pp.245-266). New Jersey, Lawrence Erlbaum Assoc., Pub.

Neundorf, K. A. (2002). The content analysis guidebook. Thousand Oaks, CA: Sage. Noelle-Neumann, Elisabeth. 1977. Turbulences in the climate of opinion: Methodological applications of the spiral of silence theory. Public Opinion Quarterly. 41 (2), 143-158. 
Oregon Chapter of the Sierra Club Group press release. (2002). Umatilla chemical weapons depot shut down due to safety problems - Oregon department of environmental quality (DEQ) called upon to revoke the army's permit to incinerate and deploy safer alternatives. Obtained at: http://www.oregon.sierraclub.org/

Portland Timeline: 1843 to 1901, City of Portland Auditor's Office. http:// www.portlandonline.com/auditor/index.cfm?c=25948\&a=11002

Reese, S. D. (2003). Prologue. In S. D., Reese, O. H. Gandy, Jr., \& A. E. Grant (Eds.), Framing Public Life: Perspectives on Media and Our Understanding of the Social World (7-32). New Jersey, Lawrence Erlbaum Assoc., Pub.

Ryan, Charlotte. (1991). Prime Time Activism: media strategies for grassroots organizing. South End Press, Boston, MA.

Scheufele, D. A. (1999). Framing as a theory of media effects. Journal of Communication. 49 (1, Winter), 103-122.

Seattle Times Staff. (1997, November 26). Nerve-gas leak detected. Seattle Times News Services, p. B2,77.

Shah, V. D., Domke, D., \& Wackman, B. D. (2004).The Effects of Value-Framing on Political Judgment and Reasoning. In S. D., Reese, O. H. Gandy, Jr., \& A. E. Grant (Eds.), Framing Public Life: Perspectives on Media and Our Understanding of the Social World (pp.227-243). New Jersey, Lawrence Erlbaum Assoc., Pub.

Stein, H. H., (2008). The Oregonian. The Oregon Encyclopedia. Portland State University. Retrieved online May 25, 2011, at: http://www.oregonencyclopedia.org/entry/ view/oregonian/ 
Stucke, M. E., Grunes, A. P. (2009). Toward a better competition policy for the media: The challenge of developing antitrust policies that support the media sector's unique role in our democracy.

The Associated Press State \& Local Wire. (2000). Whistleblower claims chemical agent escaping from smokestacks. AP. Obtained via LexisNexis Academic 4/4/2005

The Tri-City Herald (2004). Umatilla Chemical Depot News. http:// www.umatilladepotnews.com

Tichenor, P. J., Donohue, G., \& Olien, C. N. (1980). Community conflict and the press. Beverly Hills, CA: Sage.

Umatilla Chemical Weapons Depot Public Affairs Office. (2002). Weekly depot/project update- Oct.31, 2002. Available at: http://www.csepp.net/pressreleases/'02Releases/ oct31'02-weeklyupdate.html Viall, E. K. (2009). Hyper-local citizen journalism sites and traditional media sites: Similarities and contrasts in theme, objectivity, and watchdog function (Thesis). Indiana University, pp. 1-121. 


\section{Hermiston Herald Articles}

Agent antidote to be available. (1997, July 1). The Hermiston Herald, p. A1.

Army awaits go ahead for incineration. (1995, November 21). The Hermiston Herald, p. A7.

Army depot cited by DEQ. (1998, April 21). The Hermiston Herald, p. A3.

Army depot opens to public. (1995, May 16). The Hermiston Herald, p. A2.

Army depot to open for tours. (1994, May 17). The Hermiston Herald, p. A1.

Audit finds flaws in management of CSEPP funds. (1998, March 17). The Hermiston

Herald, p. A1-A2.

Carveth, C. (1997, February 11). Army plan falls short of protecting community (Letter to editor). The Hermiston Herald, p. A3.

CBS report indicates lack of safety measures (Letter to editor). (1997, February 11). The Hermiston Herald, p. A3.

Chemical depot locates 4 leaking projectiles. (1997, ). The Hermiston Herald, p. A8.

Costs, risk questioned at hearing. (1995, July 18). The Hermiston Herald, p. A9.

CSEPP donates buses to program. (1997, November 18). The Hermiston Herald, p. A7.

CSEPP program to focus on "the day after". (1997, August 19). The Hermiston Herald, p. A7.

Defense department declassifies stockpile numbers. (1996, January 23). The Hermiston Herald, p. A3. 
Department of Environmental Quality. (1996, August 20). Chemical weapons incinerator, your opinion counts! The Hermiston Herald, p. A2.

Depot discovers gas leak (1995, March 14). The Hermiston Herald, p. A1.

Depot discovers rocket leaking nerve agent. (1995, May 16). The Hermiston Herald, p. A2.

Depot name change takes effect today. (1996, October 1). The Hermiston Herald, p. A2. Depot to test warning sirens. (1997, January 21). The Hermiston Herald, p. A2.

Depots leaker notices a tactic to push incinerator (Letter to the editor). (1995, May 23). The Hermiston Herald, p. A5.

Early, C. (1994, April 12). Russians warn of dangers. The Hermiston Herald, p. A1.

Early, C. (1994, April 5). Council tables mayor's incineration motion. The Hermiston Herald, p. A3.

Early, C. (1994, February 15). Weapons incineration Plan. The Hermiston Herald, p. A1. Early, C. (1994, January 25). Army depot begins demilitarization. The Hermiston Herald, p. A3.

Early, C. (1994, July 12). \$3.7 requested for chemical defense. The Hermiston Herald, p. A3.

Early, C. (1994, March 1). Incinerator report meets critique: demilitarization group says plan contains flaws. The Hermiston Herald, pp. A1-A2.

Early, C. (1994, March 15). Officials say depot drill is beneficial. The Hermiston Herald, p. A2. 
Early, C. (1994, March 22). Officials hand out emergency pagers. The Hermiston Herald, p. A3.

Early, C. (1994, March 29). Officials: praise island type leak not likely in Hermiston. The Hermiston Herald, p. A2.

Early, C. (1994, March 8). Drill prepares team for disasters. The Hermiston Herald, p. A2.

Early, C. (1994, May 24). What the NRC report recommends. The Hermiston Herald, p. A3.

Early, C. (1994, September 13). Nerve gas leak detected at depot: officials say projectile has been sealed and poses no danger. The Hermiston Herald, p. A1.

Early, C. (1995, February 7). Workforce cut at Army depot: depot to cut 25 jobs by May. The Hermiston Herald, p. A1.

EQC to issue incineration permits Feb. 7. (1997, January 28). The Hermiston Herald, p. A3.

Evans, R. (1997, February 25). Kirkland writer supports incineration method. The Hermiston Herald, p. A4.

GAO rules RAytheon contract valid. (1998, May 5). The Hermiston Herald, p. A7. Harkenrider, Frank. (1997, April 1). Mayor welcomes Raytheon to community (Letter to editor). The Hermiston Herald, p. A4.

Incineration (year in review). (1997, January 7). The Hermiston Herald, p. A9. Incinerator impact draft released: Public will get chance to comment. (1995, December 16). The Hermiston Herald, p. A1. 
Incinerator information to be organized. (1994, November 15). The Hermiston Herald, p. A1.

Kane, M. (1996, March 19). Army opens outreach office: Aims to provide information on incineration plan. The Hermiston Herald, p. A1-A2.

Kane, M. (1996, September 17). Army looks at alternatives to incineration for 2 sites.

The Hermiston Herald, p. A1-A2.

Kane, M. (1996,m January 23). Army answers questions on incineration. The Hermiston Herald, p. A3.

Kane, M. (1997, May 20). Beginning of the end: Crowd turns out for historic event at Umatilla depot. The Hermiston Herald, p. A1-A2.

Kasley, S. J. (1998, January 13). 1997-A good year for Raytheon, its neighbors. The Hermiston Herald, p. A4.

Kennard, D. (1994, April 26). Incineration seems to be ok but smoking is ok too, right (Editor's note). The Hermiston Herald, p. A4.

Lockwood, F. (1997, December 16). FEMA, Army clarify lines of responsibility. The Hermiston Herald, p. A1.

Lockwood, F. (1997, December 16). Incineration alternatives pass beginning stage of evaluation. The Hermiston Herald, p. A2.

Lockwood, F. (1997, December 9). Work progresses on incinerator: 500 employees tackle construction. The Hermiston Herald, p. A1.

Lockwood, F. (1997, July 1). CSEPP in line for $\$ 4.3$ million in draft budget. The Hermiston Herald, p. A1. 
Lockwood, F. (1997, June 3). Construction of incinerator quietly begins. The Hermiston Herald, p. A3.

Lockwood, F. (1997, November 18). Depot 'clean' of buried chemical kits. The Hermiston Herald, p. A2.

Lockwood, F. (1997, October 7). Army official disputes claims against Raytheon. The Hermiston Herald, p. A1-A2.

Lockwood, F. (1998, April 28). Depot to host annual armed forces day. The Hermiston Herald, p. A6.

Lockwood, F. (1998, August 4). '60 Minutes' report renews criticism. The Hermiston Herald, p. A1.

Lockwood, F. (1998, January 13). '60 Minutes' returns to tape CSEPP story. The Hermiston Herald, p. A1-A2.

Lockwood, F. (1998, January 27). weapons models give public inside. The Hermiston Herald, p. A3.

Lockwood, F. (1998, June 9). Army offers to buy chemical monitors. The Hermiston Herald, p. A1-A2.

Lockwood, F. (1998, March 10). FEMA disputes ‘60 Minutes’ portrayal. The Hermiston Herald, p. A1-A2.

Lockwood, F. (1998, March 24). What to do in case of a emergency. The Hermiston Herald, p. A3.

Lockwood, F. (1998, May 12). CSEPP shows off its new protective suits. The Hermiston Herald, p. A6. 
Lockwood, F. (1998, September 22). Group calls for halt to incineration: DEQ consultants say incineration safe at Umatilla. The Hermiston Herald, p. A2.

Long, S. (1995, April 4). Chemical weapons leak again. The Hermiston Herald, p. A2

Long, S. (1995, May 30). Depot continues clean up work. The Hermiston Herald, p. A2.

Long, S. (1995, November 7). DEQ outlines tests for Army incinerator. The Hermiston Herald, p. A1.

Long, S. (1996, February 27). Mayors give show of support for incineration. The Hermiston Herald, p. A1-A2.

Lyons, A. (1996 October 22). Depot to dedicate clean-up plant. The Hermiston Herald, p. A9.

Lyons, A. (1996, July 30). Chemical weapons meeting scheduled. The Hermiston Herald, p. A3.

Lyons, A. (1996, June 4). Plan center targets incinerator work. The Hermiston Herald, p. A2.

Lyons, A. (1996, May 28). Army hears concerns on incineration plans. The Hermiston Herald, p. A1-A2.

Lyons, A. (1996, November 19). Tribes proposal may delay EQC. The Hermiston Herald, p. A1.

Lyons, A. (1996, November 26). EQC approves depot permits for incineration. EQC. The Hermiston Herald, p. A1-A2.

Lyons, A. (1996, October 1). Clinton wants review of alternatives to incineration. The Hermiston Herald, p. A2. 
Lyons, A. (1996, October 22). Tribes, Army ink deal. The Hermiston Herald, p. A1-A2.

Official defends local CSEPP expenditures. (1998, January 13). The Hermiston Herald, p. $\mathrm{A} 1-\mathrm{A} 2$.

Public notice: Related to the Umatilla chemical depot. (1997, September 9). The Hermiston Herald, p. A2.

Raytheon added to Army permit. (1998, January 20). The Hermiston Herald, p. A2.

Raytheon Co. putting cash into local community. (1997, May 27). The Hermiston Herald, p. A7.

Raytheon employment climbing. (1998, April 21). The Hermiston Herald, p. A2.

The paper farmer: DEQ examines effects of depot accident on the 'model' farmer. (1996, August 27). The Hermiston Herald, p. A8.

Training exercise set for chemical depot. (1998, MAy 5). The Hermiston Herald, p. A6.

Umatilla Army depot to undergo name change. (1996, July 30). The Hermiston Herald, p. A5.

Umatilla chemical depot puts its might on display. (1997, May 20). The Hermiston Herald, p. C1.

Umatilla depot activity record of decision available for public use (announcement). (1995, March 7). The Hermiston Herald, p. A5.

Umatilla depot activity: public invited to comment on 5 proposed cleanup plans (public announcement). (1994, February 15). The Hermiston Herald, p. A8.

Vapor detected inside structure. (1998, December 15). The Hermiston Herald, p. A1. 
Wentworth, S. (1997, April 1). CSEPP system passes test. The Hermiston Herald, p. A1A2.

Wentworth, S. (1997, April 22). Army answers claims of overspending: Former worker says JACADS spending was 'out of control'. The Hermiston Herald, p. A3.

Wentworth, S. (1997, April 22). Incineration permit draws legal action: Army says Umatilla facility will benefit from latest technology. The Hermiston Herald, p. A1-A2. Wentworth, S. (1997, February 11). EQC gives final approval for incineration at depot. The Hermiston Herald, p. A1-A2.

Wentworth, S. (1997, February 18). Official: Area not ready for disaster: Emergency program funds proving difficult to secure. The Hermiston Herald, p. A1.

Wentworth, S. (1997, January 14). Defazio warns EQC of depot's liability. The Hermiston Herald, p. A2.

Wentworth, S. (1997, March 18). Oregon's Smiths push depot safety. The Hermiston Herald, p. A1.

Wentworth, S. (1997, March 25). Morrow county seeks \$18 million from Army. The Hermiston Herald, p. A1.

Wentworth, S. (1997, March 4). Official suggest duct tape in case of disaster: Evacuation unlikely in chemical accident. The Hermiston Herald, p. A1-A2.

Wyden to host forum on depot. (1998, June 23). The Hermiston Herald, p. A3. 


\section{The Oregonian Articles}

Army hires firm to find, destroy live ordinance at depot. (1995, February 15). The

Oregonian, p. B02.

Cockle, R. (1995, June 14). Three groups appeal nerve gas decision. The Oregonian, p. B02.

Cockle, R. (1995, March 11). Second nerve gas leak occurs at Umatilla depot. The Oregonian, p. B01.

Cockle, R. (1995, March 2). Cost of chemical weapons disposal soaring. The Oregonian, p. D02.

Cockle, R. (1995, March 20). In Oregon sarin, the nerve agent. The Oregonian, p. B01. Cockle, R. (1995, November 15). Army looks at new ways to destroy nerve gases. The Oregonian, p. A01.

Delay chemical arms destruction, Umatilla tribes ask Kitzhaber. (1996, February 16). The Oregonian, p. B10.

DEQ calls hearing on plan for incinerator at Umatilla. (1995, October 26). The Oregonian, p. D02.

Don’t delay nerve gas disposal. (!995, April 28). (Editorial). The Oregonian, p. D10. Emergency officer will talk about Umatilla nerve gas. (1995, September 26). The Oregonian, p. 02.

Emergency plans topic. (1995, February 22). The Oregonian, p. C02. 
Firm to devise shelters in Hermiston-area schools. (1995, September 1). The Oregonian, p. B02.

Hermiston warning system will be loud and clear. (1995, August 17). The Oregonian, p. D02.

House OKS more money for weapons incinerator. (1995, June 22). The Oregonian, p. D02.

It would be quicker and safer to reconfigure Umatilla's M55's. (1995, May 15).

(Editorial). The Oregonian, p. B08.

Whistle-blower sues army, says he was fired illegally. (1995, June 21). The Oregonian, p. D02

A nerve gas incinerator rises. (1998, March 14). The Oregonian, p. A1.

Army outlines plan to burn chemical arms. (1996 June 16). The Oregonian, p. D05.

Brinckman, J. (1997, June 21). Study faults depot preparedness. The Oregonian, p. D01.

Burn weapons at Umatilla. (1996, November, 21). The Oregonian, p. B08.

Ceremonies break ground for depots arms incinerator. (1997, May, 2). The Oregonian, p. D07.

Cockle, R. (1996, April 6). Burning gas risky, Umatilla study says. The Oregonian, p. D01.

Cockle, R. (1996, July 24). Umatilla army depot gets a new name. The Oregonian, p.B02.

Cockle, R. (1997, July, 1). E. Oregon to receive nerve gas antidote. The Oregonian, p. C07. 
Cockle, R. (1997, May, 22). No zero risk exists, arms expert says. The Oregonian, p. D02.

Cockle, R. (1994, April 14). Plan to burn chemical weapons. The Oregonian, p. E05.

Cockle, R. (1994, August 11). Group accuses army of exaggerating M55 risk. The

Oregonian, p. D02.

Cockle, R. (1994, January 14). Weapons-burning alternatives proposal stalled. The

Oregonian, p. C03.

Cockle, R. (1994, March 22). Pentagon asks funds for Umatilla incinerator. The

Oregonian, p. B02.

Cockle, R. (1994, May 20). Umatilla told to burn chemical arms. The Oregonian, p. D02.

Cockle, R. (1996, March 26). Kitzhaber may slow papers for army nerve-gas burner. The Oregonian, p. B01.

Cockle, R. (1996, March 29). Tribes astonished by gas-burning plan. The Oregonian, p, B01.

Cockle, R. (1996, March 4). Kitzhaber may not have power to delay nerve gas burning. The Oregonian, p. B01.

Cockle, R. (1998, December 30). Morrow County looks to impact of incineration. The Oregonian, p. E2.

Contractor burns contaminated soil at Umatilla depot. (1996, August, 29). The Oregonian, p. B10.

Defazio asks state to reject permit to burn war gases. (1996, November, 21). The Oregonian, p. B10. 
Destroy Umatilla weapons. (1996, March1). The Oregonian, p. B06.

Environmental quality commission work close up. (1996, November, 15). The

Oregonian, p. E02.

Final Hearings on disposal of nerve, mustard gas set. (1996, November, 4). The

Oregonian, p. B07.

First shipment of shells leaves Umatilla depot. (1997, September 16). The Oregonian, p.

E6.

Foster, D. (1996, December, 8). Army team will inspect nerve gas incinerator. The Oregonian, p. A26.

Group to hear russian chemical weapons activist. (1994, April 13). The Oregonian, p. B02.

Hermiston aides impressed by Utah's weapons disposal. (1994, June 10). The Oregonian, p. D02.

Hermiston site of meeting on disposition of chemicals. (1996, July 11). The Oregonian, p. B03.

Hermiston wants U.S. money to deal with worker influx. (1996, October 25). The Oregonian, p. B10.

Hill, K. G. (1998, June 30). Most of Oregon sees nice growth in employment. The Oregonian, p. E1.

Incinerate weapons at Umatilla. (1996, September, 7). The Oregonian, p. D07. Incinerator builder spends $\$ 4$ million in area. (1997, November 25). The Oregonian, p. D2. 
Lawmaker criticizes army on aid to towns near depot. (1997, March 12). The Oregonian, p. D06.

Long, J. (1996, Aug, 25). What could go wrong...death by the numbers. The Oregonian, p. A17.

Long, J. (1996, August 25). Umatilla's Deadly Dilemma. The Oregonian, p. A17.

Long, J. (1996, November, 16). State may forbid army to burn mustard gas. The Oregonian, p.C03.

Long, J. (1996, November, 23). Army gets ok burn weapons. The Oregonian, p. B01. Long, J. (1996, November, 27). Incinerator unsafe, says ex-manager. The Oregonian, p. A13.

Long, J. (1997, April, 16). Groups seek rejection of Umatilla incinerator. The Oregonian, p. B14.

Long, J. (1997, February 8). Umatilla nerve gas burner advances. The Oregonian, p. C01. Long, J. (1997, February, 11). Raytheon wins nod to destroy Umatilla depot arms stockpile. The Oregonian, p. B01.

Long, J. (1997, June, 17). Oregon lawmakers ask investigation of Sarin case. The Oregonian, p. B05.

Long, J. (1997, June, 6). The season of nerve gas leaks the army sees no danger to the public, but leaks might increase the risk of M-55 rockets exploding. The Oregonian, p. B04.

Long, J. (1997, November 28). Army finds gas leak at Umatilla chemical depot. The Oregonian, p. E4. 
Long, J. (1998, August 8). Public panic a threat difficult to prepare for. The Oregonian, p. B1.

Long, J. (1998, February 15). Umatilla multiplies nerve gas protection. The Oregonian, p. B1.

Long, J. (1998, July 29). Study says nerve gas danger underestimated. The Oregonian, p. B7.

Long, J. (1998, March 7). Glitches slow incinerator safety plan. The Oregonian, p.

D1.The Oregonian

Meeting set in Hermiston on burning of nerve gases. (1997, March, 27). The Oregonian, p. D04.

Nerve gas burner in Utah gets first ok. (1994, November 26). The Oregonian, p. D01. Oregon '60 Minutes' plans to report on Umatilla chemical depot. (1997, December 21). The Oregonian, p. B4.

Oregonians should resist effort to make us guinea pigs. (1996, July 22). The Oregonian Hermiston site of meeting; p. B06.

Peterson, C. (1994). Incineration should proceed on nerve gas. The Oregonian, p. B09.

Public can testify on plan to burn Umatilla weapons. (1996, October, 30). The Oregonian, p. E04

Siren system for Umatilla faces test in Washington. (1997, March, 6). The Oregonian, p. B04.

Texas soldier will oversee Umatilla chemical depot.(1997, April, 18). The Oregonian, p. B02. 
Umatilla chemical depot could undergo inspection. (1997, September, 2). The Oregonian, p. B02.

Umatilla depot faces inspection. (1997, August, 26). The Oregonian, p. B04.

Umatilla tribes, U.S. Army plan to confer on weapon disposal. (1996, October, 25). The

Oregonian, p. B02.

Utah weapons incinerator passes 3 million pound mark. (1998, April 10). The Oregonian, p. D4.

Weapons depot tests warning system software.(1997, September, 9). The Oregonian, p. B02.

Winds at the incinerator. (1998, March 15). The Oregonian, p. A18. 


\section{Appendix-A}

Descriptive coding sheet:

article date couple words from title paper

If a problem is identified please answer the following questions:

a.) What is the problem?:

b.) What is the first solution provided, and by whom?:

c.) What is the second solution provided, and by whom?:

d.) What is the third solution provided, and by whom?:

e.) (optional) Is there anything you would like to add about the article (observations, reoccurring themes, notes, etc)? 


\section{Appendix-B}

Coding checklist:

hh Checklist

\begin{tabular}{|c|c|c|c|c|c|c|c|}
\hline $\begin{array}{c}\text { article } \\
\# \\
\end{array}$ & date & $\begin{array}{c}\text { has problem } \\
\text { Y or } \mathbf{N}\end{array}$ & $\begin{array}{c}\text { has } \\
\text { solution }\end{array}$ & $\begin{array}{c}2 \\
\text { solutions }\end{array}$ & $\begin{array}{c}3 \\
\text { solutions } \\
\end{array}$ & $\begin{array}{l}\text { episodic } \\
\text { scope }\end{array}$ & $\begin{array}{c}\text { thematic } \\
\text { scope }\end{array}$ \\
\hline 1 & Jan 25, 1994 & & & & & & \\
\hline 2 & Feb 15, 1994 & & & & & & \\
\hline 3 & Feb 15, 1994 & & & & & & \\
\hline 4 & Mar 1, 1994 & & & & & & \\
\hline 5 & Mar 8, 1994 & & & & & & \\
\hline 6 & Mar 15, 1994 & & & & & & \\
\hline 7 & Mar 22, 1994 & & & & & & \\
\hline 8 & Mar 29, 1994 & & & & & & \\
\hline 9 & Apr 5, 1994 & & & & & & \\
\hline 10 & Apr 12, 1994 & & & & & & \\
\hline 11 & Apr 26, 1994 & & & & & & \\
\hline 12 & May 17,1994 & & & & & & \\
\hline 13 & May 24, 1994 & & & & & & \\
\hline 14 & Jul 12, 1994 & & & & & & \\
\hline 15 & Sep 13, 1994 & & & & & & \\
\hline 16 & Nov 15, 1994 & & & & & & \\
\hline 17 & Feb 7, 1995 & & & & & & \\
\hline 18 & Mar 7, 1995 & & & & & & \\
\hline 19 & Mar 14, 1995 & & & & & & \\
\hline 20 & Apr 4, 1995 & & & & & & \\
\hline 21 & May 16, 1995 & & & & & & \\
\hline 22 & May 16, 1995 & & & & & & \\
\hline 23 & May 23, 1995 & & & & & & \\
\hline 24 & May 30, 1995 & & & & & & \\
\hline 25 & Jul 18, 1995 & & & & & & \\
\hline 26 & Nov 7, 1995 & & & & & & \\
\hline 27 & Nov 21, 1995 & & & & & & \\
\hline 28 & Dec 19, 1995 & & & & & & \\
\hline 29 & Jan 23, 1996 & & & & & & \\
\hline 30 & Jan 23, 1996 & & & & & & \\
\hline 31 & Feb 27, 1996 & & & & & & \\
\hline
\end{tabular}

